erosional incision of the Nile River Valley abstracted from his 1967 monograph (Chapter 44.3).

Later that winter, through the kindness of William A. Berggren of the Woods Hole Oceanographic Institution, I was put in touch with F. T. Barr of the Oasis Oil Company of Libya. A buried channel system had been discovered beneath the desert sands of the Sirte Basin of northern Libya. Dr. Barr, at that time unaware of I. S. Chumakov's investigations of the Nile Valley, was speculating to a not too receptive audience that a sudden drop in sea level during late Miocene time could have been responsible for the deep drainage erosion observed. Shortly afterwards he came for a brief visit to Lamont-Doherty Geological Observatory, where I invited him to document these findings in Chapter 44.4, of this volume. His report prepared in conjunction with B. R. Walker, represents work done prior to, and completely independent of, the Deep Sea Drilling Project cruise in the Mediterranean.

That summer, during the Fifth Congress on the Neogene of the Mediterranean in Lyon, France, our shipboard paleontologist, Maria B. Cita, presented a formal paper on the Deep Sea Mediterranean Neogene Stratigraphy and mentioned the desiccation hypothesis. According to correspondence from her, the reaction to the hypothesis was very mixed; one of the strongest arguments against it being the lack of geomorphological evidence that would accompany such a catastrophic happening. At the meeting, Dr. Georges Clauzon of the Laboratoire de Géographie Physique of the University of Provence came to her defense and recalled the observations of G. Denizot (1951) on the cutting of the Rhone Valley. Dr. Clauzon kindly agreed to write for us a brief documentation of the erosional epoch in the western Mediterranean since the previous two reports in this chapter had only dealt with the eastern basins. My appreciation is extended to him for the speed and care he took in getting his report (Chapter 44.5) to Professor Cita for translation into English.

Thanks is here expressed to Arvedo Decima, Forese C. Wezel, F. T. Barr, and B. P. Walker for so generously contributing their ideas and new data to this chapter. I congratulate I. S. Chumakov for his superb documentation, which you are strongly encouraged to read in its entirety in the original publications, and for allowing us to abstract from his papers and correspondence.

It is not often that collaborating evidence from such diverse and independent sources comes together so quickly. In each of the cases, when the interpretations based on a single study were reported they were found generally to be unconvincing to others. Of all the investigations, that of the Glomar Challenger was the last to occur. It is a tribute to the vision of people in the U. S. National Science Foundation and in the JOIDES consortium that the soundly conceived program of Deep Sea Drilling was able to provide the catalyst to what is to me the incredibly bold idea that an entire ocean can dry up.

\section{REFERENCES}

Chumakov, I. S., 1967. Pliocene and Pleistocene deposits of the Nile Valley in Nubia and Upper Egypt (in Russian). Acad. Science USSR, Geol.-Institute, Trans., Moscow. 170,5 .

, 1971. Some points of the late Miocene-early Pliocene geological history of the Mediterranean basin by new data (in Russian). Sovetskaya Geologiya. 10.

Geological history of the Mediterranean at the end of the Miocene-the beginning of the Pliocene according to new data, (abstract in Russian). Bull. Moscow Soc. of Naturalists. 46 (3).

Denizot, G., 1951. Les anciens rivages de la Mediterranee Francaise. Bull. Inst. Ocean., Monaco. No. 992.

Hardie, L. A., and Eugster, H. P., 1971. The depositional environment of marine evaporites: A case for shallow, clastic accumulation. Sedimentology. 16, 187.

Ogniben, L., 1957. Petrografia della Serie Solfifera Siciliano e considerazioni geologiche relative. Mem. Descrit. Carta. Geol. Ital. 33, 275 pp.

Ryan, W. B. F., Hsü K. J., Nesteroff, W. D., Pautot, G., Wezel, F. C., Lort, J. M., Cita, M. B., Maync, W., Stradner, H., Dumitrica, P., 1970. Deep Sea Drilling Project, Leg 13. Geotimes. December. 12.

Selli, R., 1960. Il Messiniano Mayer-Eymar 1867. Proposta di un neostratotipo. Giorn. Geol. 28 (fasc. 2), 1.

\title{
44.1. LATE MIOCENE EVAPORITES OF THE CENTRAL SICILIAN BASIN, ITALY
}

\author{
Arvedo Decima, Ente Minerario Siciliano, Palermo, Italy \\ and \\ Forese C. Wezel, Istituto di Geologia, Palazzo delle Scienze, Catania, Italy
}

\section{INTRODUCTION}

The Mediterranean Sea is a complex of small basins, completely surrounded by land. In order to reconstruct the regional structure and evolution of the Mediterranean region, it is of primary interest to compare and correlate the rocks beneath the sea floor with the stratigraphic units mapped on the borderland. In this respect, DSDP Leg 13 
drilling provided a unique opportunity to bridge the gap between geological and geophysical studies made at sea and those made on land.

Around the western Mediterranean basin, late Miocene evaporite deposits outcrop in southern Spain, northern Africa, and Italy. The Sicilian evaporite succession is peculiar owing to its great thickness and completeness (gypsum, halite, and potash deposits). The upper part of the sequence is time-equivalent with the evaporite sections cored at Sites 124, 134, 132, and 125 (Figure 1).

The late Miocene Solfifera Series outcrops widely in the central Sicilian Basin, or Caltanissetta Trough. This basin is a graben filled in by a huge quantity of plastic sediments and gravity slides varying in age from the middle Miocene to the Quaternary. The graben is about $140 \mathrm{~km}$ long by about $80 \mathrm{~km}$ wide.

The Solfifera Series of Sicily is very important from an economic point of view because it contains mineable deposits of sulfur, halite, and potash salts, the last of which are the only ones found in Italy.

The Solfifera Series has been the subject of several papers, including the petrographic monograph of Ogniben (1957) and the recent paper on regional sedimentology by
Hardie and Eugster (1971). Whereas the above quoted works give a detailed study of parts of the Series, we intend in this paper to give an overall picture of the regional distribution and temporal succession of the sedimentary facies, and also possible interpretations of the depositional environment. The picture which emerges brings out new aspects which we believe useful not only for an interpretation of the Sicilian Basin evaporites but also for a better understanding of the Mediterranean salt deposits (see Chapters 21,22 , and 43 of this Volume).

\section{STRATIGRAPHY}

The Solfifera Series is an evaporitic section between the late Tortonian marls and the early Pliocene Trubi Formation. By general agreement, these evaporitic deposits are considered to represent the Messinian Stage (Selli, 1960). Generally speaking, the evaporitic succession is not continuous, but is divided into two parts because of the intra-Messinian tectonic deformation. Evidence for the existence of this tectonic phase comes both from field observation and from interpretation of several wells.

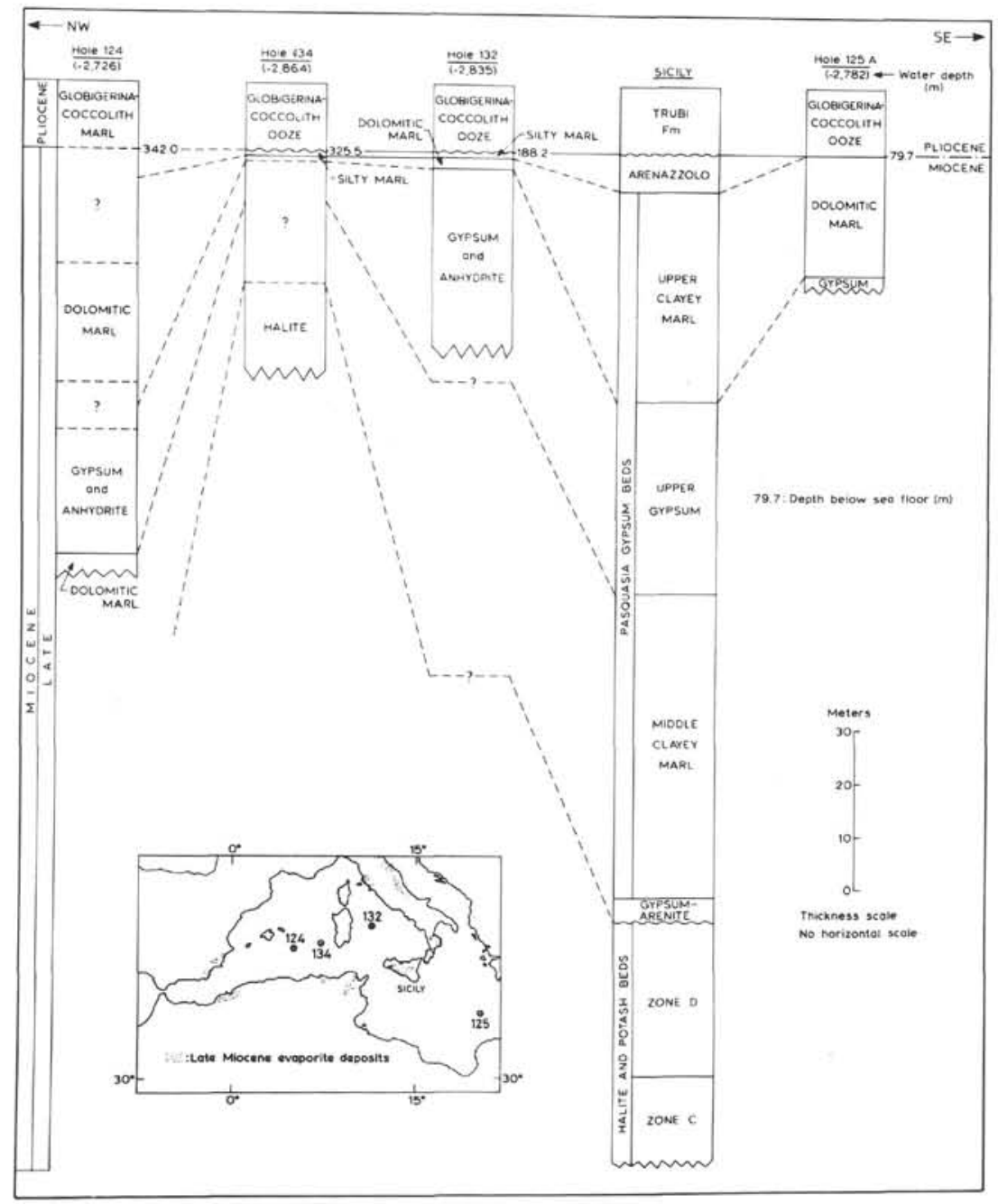

Figure 1. Tentative correlation of evaporite sequences in the DSDP drill sites and in Sicily. The names given to units of the Pasquasia gypsum beds are taken from Selli (1960). 
The stratigraphic succession we reconstruct is different from that commonly accepted. Previously, (cf. in particular Ogniben, 1957) the Series was considered to consist of the following units, from bottom to top: (1) the Tripoli Formation; (2) the Basal Limestone; (3) the Gypsum Formation with salt lenticular bodies and gypsum-arenites; and (4) the Trubi Formation with a transgressive basal unit represented by the Arenazzolo Formation. Our interpretation differs from the previous ones in that we have distinguished successions within the Series belonging to several paleogeographically distinct zones. To generalize, there are essentially two zones, that is, a marginal zone (typically developed to the southeast of the line running from Agrigento to Caltanissetta, and to the northwest of the line Sciacca-Nicosia) and a basin zone or Cattolica zone (Figure 2). These lateral differentiations are much more evident in the first part of the Solfifera Series (the lower group) than in the second (the upper group).

\section{The Lower Group}

\section{The Marginal Zone}

The succession consists of two units: (1) the Tripoli Formation $(0-60 \mathrm{~m})$ and $(2)$ the Basal Limestone $(0-80 \mathrm{~m})$.
The Tripoli Formation in outcrop is made up of alternations of white diatomites with fish remains and marls. It is a euxinic deposit containing a sparse foraminiferal fauna of planktonic forms and, occasionally but very rarely, benthonic associations (Bulimina fauna, Di Napoli Alliata, 1952). The unit grades to the Basal Limestone and consists of an alternation of marls, calcilutite beds, and powdery breccia. All authors who have studied this unit agree in interpreting it as shallow-water lagoonal sediment.

\section{The Cattolica Basin Zone}

This section contains, from bottom to top: (1) Tripoli Formation or Whitish Marls (0-20 m); (2) Massive selenite beds (the Cattolica gypsum beds up to $250-300 \mathrm{~m}$ thick); (3) Gypsum turbidites (up to a maximum of $150 \mathrm{~m}$ ); and (4) Halite and potash beds (average thickness of 400-500 m, maximum of about $800 \mathrm{~m}$ at Porto Empedocle).

1. The Tripoli Formation of Whitish Marls-Compared to the Marginal Zone, the unit consists of earthier deposits with more frequent planktonic and benthonic faunas. In certain areas one observes shelly marls immediately in contact with the overlying gypsum beds instead of the Tripoli Formation. These whitish marls are characterized by frequent foraminifera, both planktonic and benthonic

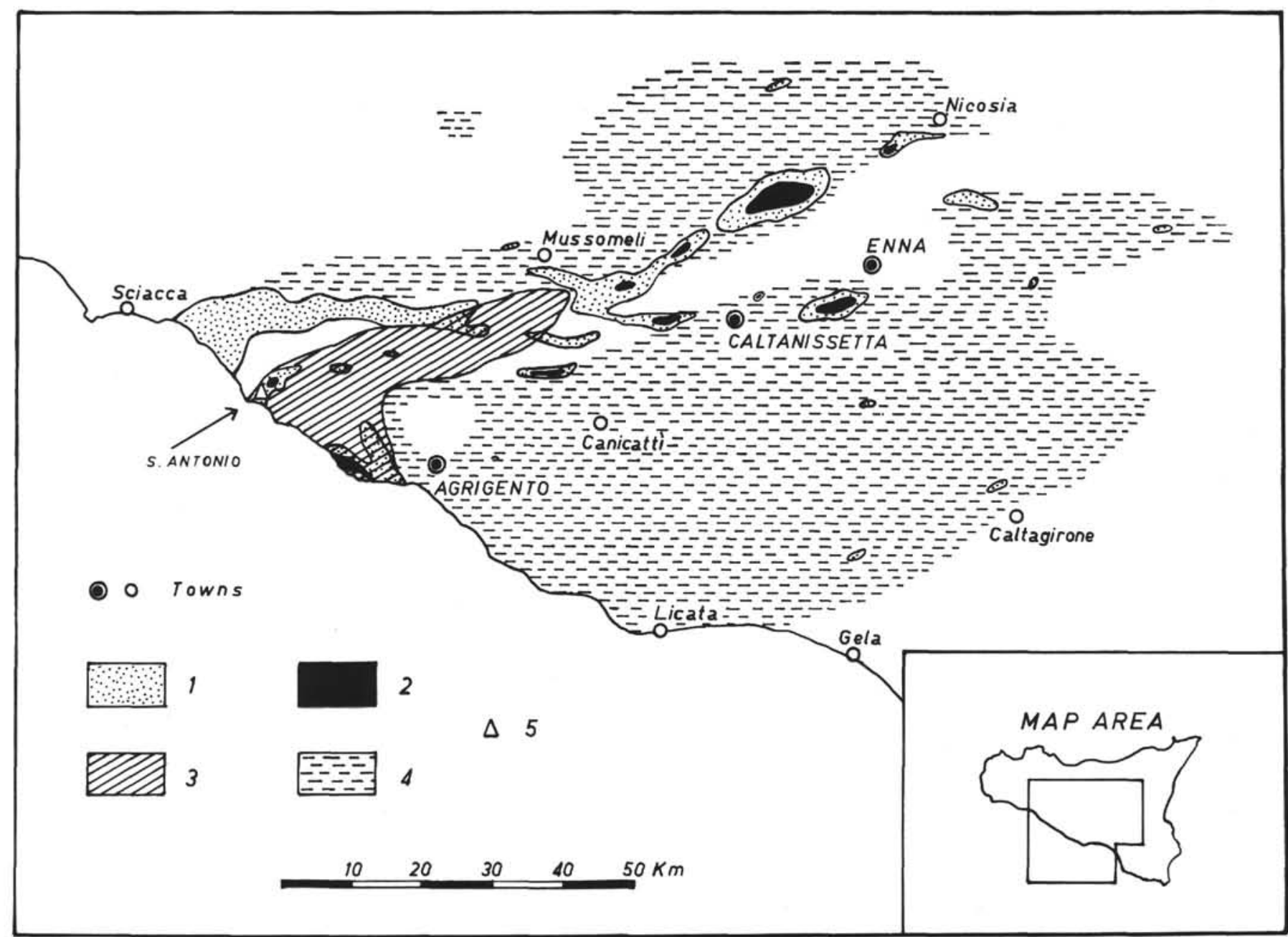

Figure 2. Regional facies distribution map showing the outcrop areas of the lower group of the Solfifera Series in the Central Sicilian Basin. Cattolica is about $23 \mathrm{~km}$ northwest of Agrigento; Pasquasia is about $8 \mathrm{~km}$ northeast of Caltanissetta. (1) the halite beds; (2) the potash beds; (3) the Cattolica gypsum beds; (4) the Basal limestone; (5) the Sant'Antonio wells. 
(ratio P:B about 1). Of the former, about 75 per cent of the pelagic fauna are small Globigerina quinqueloba. Among the latter, Bolivina (dentellata and dilatata) and Rectuvigerina (gaudrynoides and siphogerinoides) are vastly predominant. This predominance of the two benthonic genera seems to indicate a low-oxygen environment, perhaps similar to that present in the Santa Barbara basin as described by Harman (1964). In the Sant'Antonio well number 9 (Figure 2), the marls underlying the Cattolica gypsum beds are black, bituminous, and odoriferous.

2. The Cattolica gypsum beds-Generally, the formation begins with a sharply defined boundary, sometimes preceded by some few centimeters of laminated white limestone. The gypsum appears as massive beds of coarse, twinned selenite crystals. These beds are up to 20 meters thick and constitute a sequence without pelitic intervals. However, two odiferous bituminnous marly intercalations have been observed in Sant'Antonio well number 9 and there is another outcropping near S. Angelo Muxaro. In the field, the selenite sections are found broken up into separate blocks, each of which often contains vertical beds. This breaking up is believed to be related to the intraMessinian tectonic phase.

The sections begin with a lower zone some 20 to 50 meters thick made up of thick homogeneous coarse selenite crystal beds (with crystals up to $20-30 \mathrm{~cm}$ ). There follows a zone characterized by thinner selenite beds, alternating with carbonate laminae and layers less than one meter thick. Toward the top, the carbonate laminae become more and more irregular and undulated. The carbonate layers cover the selenite crystals of the underlying beds; in some cases the selenite crystals extend through the laminae. Field observations lead us to infer that recrystallization of the selenite took place immediately after the deposition of the carbonate laminae, which were deformed during this process.

deformed during this process.

The laminae and the carbonate layers are more abundant and more irregular in the northern part of the Cattolica Zone (the Casteltermini area, Figure 2). To the southeast of Mussomeli, there is some evidence of a lateral passage between the Basal Limestone and the Cattolica gypsum beds (Bommarito, 1965, personal communication). The presence of this transitional zone indicates that the Basal Limestone and the Cattolica gypsum beds are two synchronous deposits in basins of different depth.

Hardie and Eugster (1971) interpret this alternation of selenite-carbonate laminae as clastic deposits deposited in a shallow lagoon-littoral flat complex. While we have no sedimentological evidence for contradicting their interpretation, the geological data lead us to believe instead in a deep-water deposition (Cattolica basin). The reasons for our position are: (a) the fact that the gypsum beds lie between deep-water euxinic deposits and overlying gypsum turbidites; (b) the fact that the pelitic intercalations in the selenite beds in the Sant'Antonio well number 9 consists of bituminous marls similar to the ones underlying the gypsum; and (c) the great thickness (up to 250-300 m) and homogeneity of the Cattolica gypsum beds both in outcrop and in the wells.
As regards the nature of the gypsum, we have so far found no evidence for contending that it is resedimented clastic gypsum which was later recrystallized as selenite. On the other hand, the sharp lower boundary of the gypsum formation tends to favor the hypothesis of a sudden supply of resedimented gypsum material into the basin. There may also be a connection between the sudden gypsum deposition and $\mathrm{CaSO}_{4}$ enrichment of the basin water due to the arrival of dense brines from the Marginal Zone. Either in situ precipitation of primary gypsum, or gypsum detritus resedimentation, seems to us to be the possible explanations for the genesis of the Cattolica gypsum beds. The origin of the carbonate laminae, however, is still an open question.

3. Gypsum turbidites-So far these deposits have not been found in the field, but only in the wells. They are typically developed in Sant'Antonio well number 1 where they were drilled for 150 meters below the salt deposits without reaching the base. In Sant'Antonio well number 9, seven gypsum turbidite beds were drilled through to a thickness of 70 meters before reaching the Cattolica gypsum beds. The turbidites are made up of graded gypsum sands (with the maximum size of selenite clastics about one $\mathrm{cm}$ ) also containing intraclasts of pyritic marls. The sands grade toward the top into green pyritic marls with abundant foraminifera, which are for the most part reworked from Tortonian marginal clays. Alternating with the turbidites are thin pelitic foraminifera-devoid layers or beds with small Globigerina spp. (e.g. G. quinqueloba) which we believe to be indigenous. These pelitic layers are thought to be pelagic deposits deposited between one turbidity current and the next. The turbidites seem to have proximal features, i.e., their great thickness (up to $15 \mathrm{~m}$ ) and the rare presence of pelagic intercalations.

4. The halite and potash beds-These deposits have been studied in several wells and in mines. At present they constitute independent bodies located mostly in a line within a narrow area between Nicosia and Sciacca (Figure 2 ). The salt deposits are diapirically folded and markedly compressed tectonically, so that the apparent thickness sometimes exceeds one kilometer. The stratigraphy of these deposits can be schematically described as follows:

a. There exists a basal breccia (up to $2 \mathrm{~m}$ ) which is composed of frequently bituminous anhydrite and black marl fragments. Sometimes the breccia is even present two meters above the base, intercalated in the halite beds (Sant'Antonio well no. 7). Black and fetid laminated anhydrite is associated with the basal breccia.

b. Salt deposits. In the area between Agrigento and Cattolica, a succession of four units has been observed and informally named A, B, C, and D. At the moment, it is not possible to extend this succession to all the Sicilian salt deposits. Zone A, at the bottom, is made up of halite with nodular anhydrite. Going upwards, there exists halite with frequent anhydrite laminae becoming thinner toward the top, and finally pure homogeneous halite (more than $98 \%$ $\mathrm{NaCl}$ ). The overlying Zone B is halite with intercalation of potash and magnesium salts. Predominantly, there are kainite beds and, in some small saline bodies, there are carnallite, sylvinite, kieserite, and bischofite. The potash salts are correlatable over some $20 \mathrm{~km}$. Zone C, about 
50-60 meters thick, has a particular type of coarse and very pure halite with intercalated anhydritic laminae, each 10 to $30 \mathrm{~cm}$. These saline deposits are capped by Zone D, which is represented by dark green anhydrite marls at the base, then by laminated anhydrite, and finally by halite similar to that of Zone A, but with thicker and more frequent anhydrite laminae.

The kainite beds of Zone $\mathrm{B}$ in the Agrigento and Cattolica area are grouped into six intervals up to ten meters thick intercalated in the halite body. Inside the six intervals, the individual kainite beds are folded and deformed with slump-type structures, whereas the halite beds at the bottom and top are undisturbed. This is a question of submarine sliding of the kainite in the Cattolica basin which was precipitated in the higher concentrated water of the marginal zone. The remarkable correlation of these slumped intervals seems to indicate a synchronous sliding downslope. This is further evidence of the relative depth of the Cattolica basin at the time of the saline deposition. We relate the downslope slumping to the Messinian tectonic deformation, which reached a paroxysm at the end of the saline deposition.

The evidence for this tectonic phase, which probably started at the time of the gypsum turbidite deposition, is as follows:

(1) The sharp angular unconformity between the Cattolica gypsum and the overlying Pasquasia gypsum beds (e.g., the $40^{\circ}$ angular unconformity observed in the Montallegro area);

(2) Several wells which show that the Pasquasia gypsum beds overlie all the underlying units. At Realmonte, for example, the Pasquasia gypsum beds transgress the basal marls, the Cattolica gypsum beds, and the different salt zones;

(3) The existence of argillaceous breccias (with gypsum and limestone blocks) emplaced between the Basal Limestone and the Pasquasia gypsum beds (e.g., the Aragona and Comitini area). This olistostrome-type deposit has been described by Mezzadri (1962-63, no. 33, p. 12).

The tectonic phase could be identified in the Messinian neostratotype succession (Selli, 1960) with the gypsumarenites intercalated in the Gessi inferiori.

\section{The Upper Group}

The Upper Group is represented by the Pasquasia gypsum beds (i.e., the alternation of gypsum and marls in the Pasquasia section described by Selli (1960) and the Arenazzolo formation.

\section{The Pasquasia Gypsum Beds}

This unit consists of six or seven balatino (laminated gypsum) and selenite beds alternating with marls. According to Decima (1964), these six or seven gypsum beds are correlatable from the Pasquasia area to the Eraclea Minoa area over a distance of about $85 \mathrm{~km}$. The only difference is that the more northerly successions are more condensed. Along the northern edge of the outcropping area, corresponding with the Madonie and Sicani Mountains, the unit becomes predominantly detrital and has sandstone and limestone fragments.
Each of the six or seven cycles consists, from bottom to top, of: Ammonia tepida and Cyprideis marls, graded and laminated planktonic foraminiferal sand, laminated calcareous marls with rare planktonic foraminifera, laminated gypsum (balatino), and finally selenite. We interpret this as a complete cycle which is characteristic of an initial transgressive phase followed by a longer regressive phase. During the final stage of the regressive phase, the foraminiferal sand and the mechanically formed gypsum laminae (balatino) were probably deposited in a few meters of lagoonal water, possibly by means of the depositional processes described by Hardie and Eugster (1971).

The following hypotheses have been proposed so far concerning the selenite crystals origin: (a) paradiagenetic transformation of a primary anhydrite (Ogniben, 1957); (b) recrystallization from an original fine-grained primary gypsum (Rabbi and Ricci Lucchi, 1969); and (c) recrystallization from an original coarse-grained gypsum, mechanically deposited (Hardie and Eugster, 1971).

On the basis of observational data on modern evaporites given by Hardie and Eugster (1971), hypothesis (a) seems to be excluded. We consider both (b) and (c) to be possible. We are inclined to apply hypothesis (b) to the case of well-oriented selenite crystals, and hypothesis (c) to less regularly-ordered twinned selenite crystals.

The gypsum deposition ended at each periodical flooding of the lagoon thus giving rise to the subsequent cycle. At the time of flooding, the lagoonal depth, as estimated from benthonic formanifera, must have been less than 50 meters.

\section{The Arenazzolo Formation}

This unit is a clastic deposit extant over the whole of central Sicily. In the Centuripe area, it is formed of coarse-grained sand composed of metamorphic and igneous rock fragments, micas, feldspars, and quartz. At Agrigento, on the other hand, the unit is made up of a silty marl. This deposit may be interpreted as an original fanglomerate deposited at the foot of the Peloritan Mountains.

\section{The Trubi Formation}

The Sicilian Solfifera Series is sharply capped everywhere by pelagic foraminiferal marls, the so-called Trubi of early Pliocene. They are a unit, up to 100 meters thick, which is composed of creamy white marls and calcareous marls with very abundant planktonic foraminifera (up to 2,300 foraminifera per gram of sediment, of which $97-98 \%$ are planktonic).

Frequent Sphaeroidinellopsis (subdehiscens and seminulina) are present in the basal Trubi marls all over Sicily, including the area to the north of the northcoast mountain ridge. The following bathymetrically significant benthic species are always found at the base of the unit:

Cassidulina subglobosa (150-600 meters according to Ingle, 1967)

Karreriella bradyi (150-800 meters according to Bock, 1971)

Planulina ariminensis (65-4020 meters, preferably between 200 and 500 meters according to Bock, 1971) Uvigerina peregrina (150-600 meters according to Ingle, 1967). 
From the bathymetric figures contained in this list, it would seem, in all probability, that the latest Sicilian evaporites deposited are those which are located at a depth of between 200 and 500 meters below the mean oceanic water level (i.e., the late Miocene Atlantic sea-level). In fact, we consider the sudden beginning of the Trubi sedimentation to be related to the geologically instantaneous submergence of the Mediterranean area (see Chapter 47 of this Volume) by Atlantic water.

\section{SUMMARY AND CONCLUSIONS}

Our regional geological study of the late Miocene Solfifera Series in central Sicily has shown that these evaporites are divided into two parts by a tectonic phase with paroxysmal compression following the halite and potash salt sedimentation.

The lower group of deposits is characterized by stagnant and carbonate facies in the marginal zone, and by a thick coeval succession of deep-water euxinic sediments and saline-evaporitic deposits in the southernmost Cattolica (i.e., the Cattolica selenite beds and the halite-potash deposits). In the Cattolica evaporitic succession, there are sometimes intercalated euxinic sediments, turbidite, and slump deposits. The geological and micropaleontological evidence seems to support the concept that the Cattolica deposits were deposited in a relatively deep basin (the Cattolica Basin). How the evaporites were deposited in this basin is still an open question. It could have been by in situ precipitation, by clastic resedimentation from the marginal zone, or, as seems more likely to us, by a combination of both.

The upper group of deposits, represented by cyclic evaporitic facies with marl, balatino, and selenite (the Pasquasia gypsum beds), was, according to us, deposited in a shallow strand-line lagoonal environment.

At the beginning of the Pliocene, the opening of the Straits of Gibraltar caused a sudden, catastrophic, "great flood", which brought into the whole Mediterranean area pelagic deposits (e.g., the Trubi Formation) which covered the Miocene evaporites. The benthonic foraminifera at the base of the Sicilian Trubi Formation lead us to believe that the evaporites of central Sicily were probably deposited from 200 to 500 meters below the Atlantic sea level.

\section{ACKNOWLEDGMENTS}

Forese Wezel thanks the Deep Sea Drilling Project for having given him the opportunity to participate on Leg 13 of the Glomar Challenger cruise in the Mediterranean Sea.

\section{REFERENCES}

Bock, W. D., 1971. Paleoecology of a section cored on the Nicaragua Rise, Caribbean Sea. Micropaleontology. 17 (2), 181 .

Decima, A., 1964. Ostracodi del Gen. Cyprideis JONES del Neogene e del Quaternario italiani. Palaeont. Italica. 57, 81 .

Di Napoli Alliata, E., 1952. Foraminiferi pelagici e facies in Italia (dal Cretacico ad oggi). 7th Convegno Nazionale del Metano e del Petrolio. 1, 3

Hardie, L. A. and Eugster, H. P., 1971. The depositional environment of marine evaporites: a case for shallow, clastic accumulation. Sedimentology. 16 (3/4), 187.

Harman, R. A., 1964. Distribution of foraminifera in the Santa Barbara Basin, California. Micropaleontology. 10 (1), 81 .

Ingle, J. C., 1967. Foraminiferal biofacies variation and the Miocene-Pliocene boundary in Southern California. Bull. Am. Paleont. 52 (236), 217.

Mezzadri, P., 1962-63. La Serie gessoso-solfifera della Sicilia. Lo Zolfo. No. 30-37.

Ogniben, L., 1957. Petrografia della Serie Solfifera siciliana e considerazioni geologiche relative. Mem. Descr. Carta Geol. Italia. 33, $275 \mathrm{pp}$.

Rabbi, E. and Ricci Lucchi, F., 1969. Sulla genesi del gesso selenitico di Pietralacroce. Giorn. Geologia. 35 (4), 137.

Selli, R., 1960. Il Messiniano Mayer-Eymar 1867. Proposta di un Neostratotipo. Giorn. Geologia. 28, 1. 
A. DECIMA, F. C. WEZEL

NE

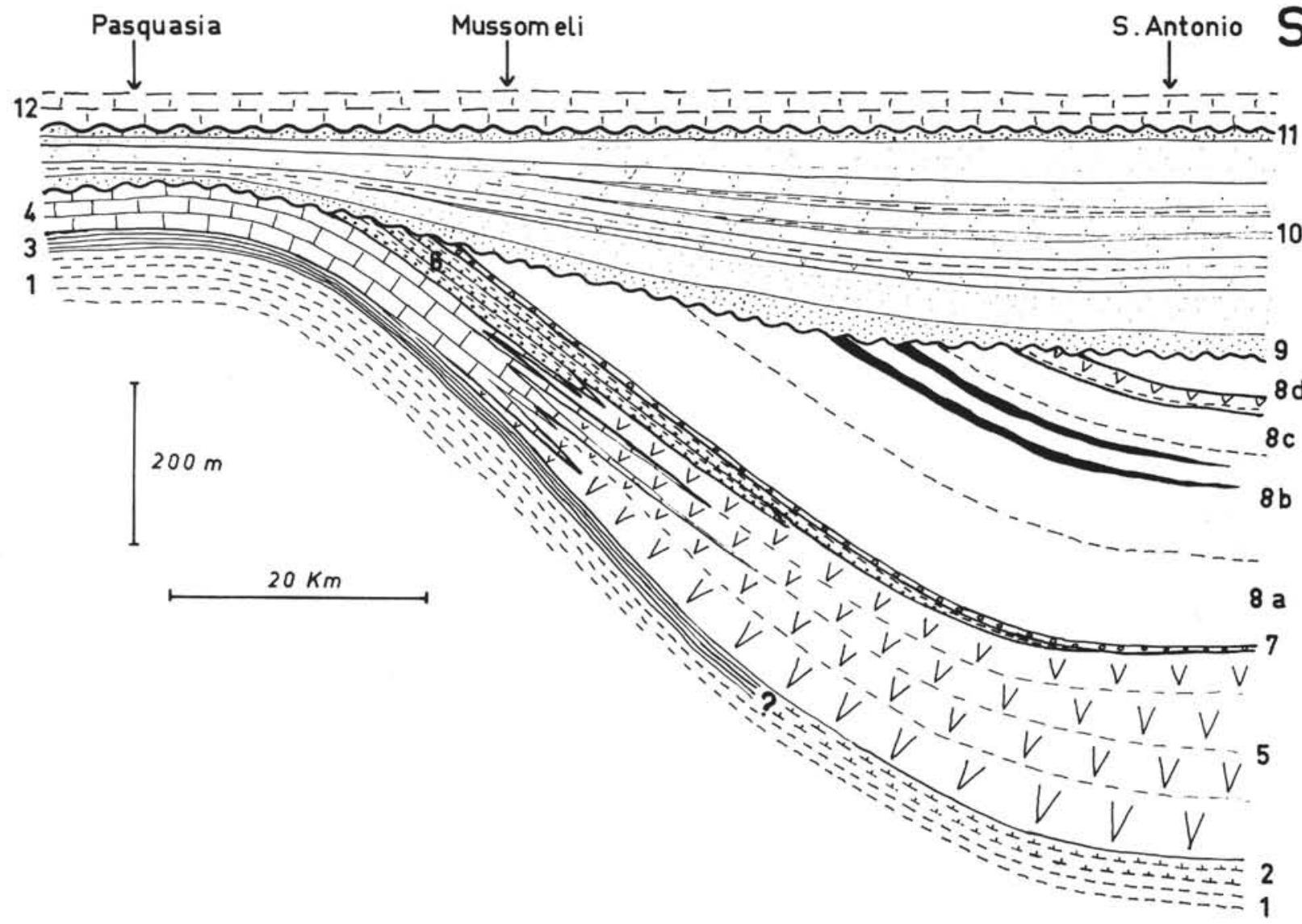

Figure 3. NE-SW stratigraphic section of Solfifera Series along the line approximately correspondent to the Cattolica basin axis. The lower group of the Solfifera Series (Nos. 1-8): (1) the marly clays of the early Messinian; (2) the Whitish Marls; (3) the Tripoli Formation; (4) the Basal Limestone; (5) the Cattolica gypsum beds; (6) the gypsum turbidites; (7) the marly-anhydritic basal breccia; (8a-8d), the halite and potash beds: respectively "Zone A", "Zone B" with intercalations of potash salts, "Zone C", "Zone D" with basal dark anhydritic marls. The upper group of the Solfifera Series (Nos. 9-11): (9) transgressive gypsum-arenites; (10) the Pasquasia gypsum beds; (11) the Arenazzolo. The Trubi Formation: No. 12. Localities shown in Figure 2. 

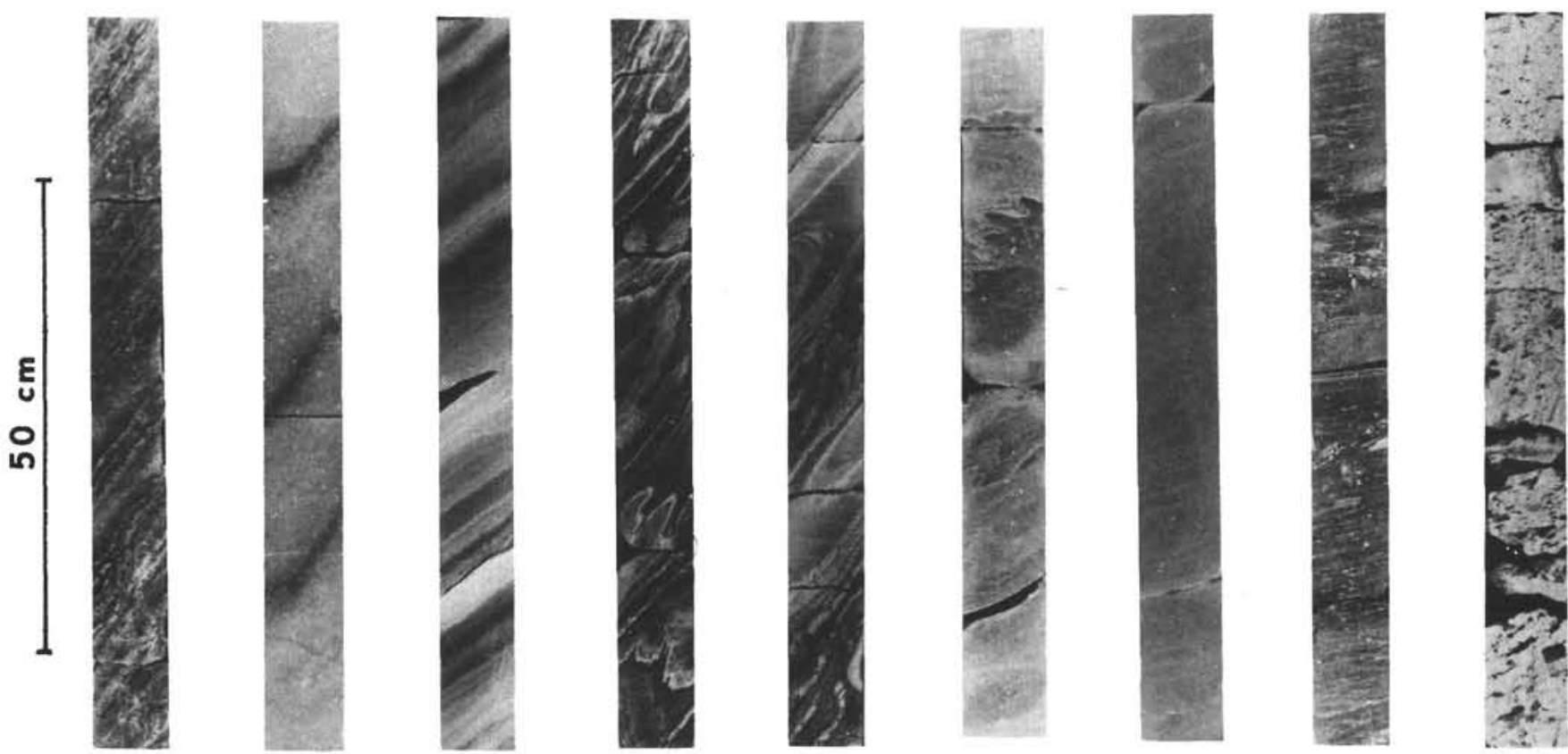

1

Figure 4. Core specimens of the Solfifera Series showing some typical saline facies: (1) halite with anhydritic laminae of "Zone D"; (2) halite of "Zone C"; (3) halite of the upper part of "Zone B"; (4) folded kainite beds of "Zone B"; (5) folded kainite beds intercalated in the halite ("Zone B"); (6) halite with anhydritic laminae (basal part of "Zone B");

(7) pure and dense halite of the upper part of "Zone A"; (8) halite with laminated and nodular anhydrite of lower part of "Zone A"; (9) the marly-anhydritic basal breccia.

\title{
44.2. GEOLOGICAL HISTORY OF THE MEDITERRANEAN AT THE END OF THE MIOCENE- THE BEGINNING OF THE PLIOCENE ACCORDING TO NEW DATA
}

\author{
I. S. Chumakov, Geological Institute, USSR Academy of Sciences, Pyzhevsky per. 7, Moscow-17, USSR
}

As a result of the extensive geological and oceanographic research conducted in the Mediterranean by West European and Soviet scientists mostly after the second World War, it seems possible now to give a fuller background of the processes that determined the main features in the geological history of the Mediterranean at the end of the Miocene and the beginning of the Pliocene.

The situation of a shrinking of the area occupied by the Mediterranean, the tendency for which became manifest during the middle Miocene, and its connection with the Atlantic ocean having been reduced to two straits (Northern or Bettian and Southern or Riphian) ended during the upper Miocene with a complete break in this connection and a general regression of the closed basin. The traces of this regression are reflected by; a pronounced shrinking of the development area of upper Miocene deposits, their lithological peculiarities (evaporite series of Messinian suite, the specific nature of the fauna (permanent presence of distrophic forms), as well as by a general incision of the entire river network to a new, very low, base level of erosion. It seems that the reason for the break in communication between the Atlantic Ocean and the Mediterranean was a drop in the ocean level during the upper Miocene. An uplift of the area of the straits (the south of Spain and the north of Morocco) only served to consolidate this break. The regression of the Mediterranean was caused by a deficit in humidity in this area and reflects its desiccation and disintegration into a number of isolated 


\title{
I. S. CHUMAKOV
}

seas-lakes. In each such sea or lake there could, naturally, have existed both extremes of salinity, as well ąs intermediary conditions of normal salinity. Correspondingly, the fauna of these basins includes elements typical of salinity regimes in their different parts. In addition to the already known facies of the Messinian suite, there should be present here still unestablished deposite of big river deltas- The Rhône, Nile, Oront (Nahr-El-Asi). The extent of overdeepening of these rivers and the structure of some of the underground canyons studied, warrant an assumption of a drop in the level of the upper Miocene Mediterranean (as compared with the present) of about $1-1.5 \mathrm{~km}$.

The next, lower Pliocene, transgression indicated by Plaisancian suite deposits (Tabianiano, Piacenziano, Astian) took place as the result of communication being established between the Atlantic ocean and the Mediterranean through the Gibraltar strait along a deep fault. Owing to a great difference in levels of the sea and the ocean this transgression was instantaneous (in the geological meaning of this word). That is why Gibraltar proved to be only slightly affected by abyssal erosion, and the sea waters that penetrated along the overdeepened river valleys of both continents (the Rhone-for $240 \mathrm{~km}$ from the present mouth, the Nile-over $1200 \mathrm{~km}$, Oront-about $150 \mathrm{~km}$ ) transformed them into deep estuaries.

Under such conditions, the accumulation of a thick mass of Pliocene sediments began with clays and marls having an absence of facies characteristic of the usual transgressive series. All the events mentioned affected the character of the Pliocene and Pleistocene fauna of this sea: the abyssal fauna is very poor and non-typical, endemism is poorly expressed, and littoral and sublittoral forms are predominantly of Lusitanian origin.

\subsection{PLIOCENE AND PLEISTOCENE DEPOSITS OF THE NILE VALLEY IN NUBIA AND UPPER EGYPT}

\author{
Abstracted from Chumakov (1967)
}

\begin{abstract}
Marine deposits of Pliocene age have been discovered in the Nile Valley at a considerable depth below sea-level. These deposits have not only been detected in lower Egypt where the base of the upper Pliocene near Cairo has been established at -300 meters, but more recently in the High Dam area at Aswan. During the course of geological investigation in this area, lower Pliocene marine and estuarian sediments were encountered at -170 (and maybe $-200)$ meters in a narrow incision into the bed of the paleo-Nile River. The overdeepening of this riverbed involved extensive erosion into a crystalline basement of gneiss and granite.

The gradient of the bedrock floor of the buried valley of the Nile above Aswan indicates that the Pliocene sea formed a deep estuary in the Nile Valley, which penetrated upstream of Wadi Halfa, in the Sudan, some 1250 miles from the present seacoast.

Cross-sections reconstructed from boreholes south of the Aswan Dam are illustrated in Figure 1. The lower part of the Pliocene sequence $\left(\mathrm{N}_{2}^{1} \mathrm{~m}\right)$ was deposited in a salt water estuary revealing the maximum extent of the
\end{abstract}

Pliocene transgression, which in the Mediterranean region is usually expressed by the Plaisancian. The middle transitional layer $\left(\mathrm{N}_{2}{ }^{2}\right)$, dated as Astian, shows a gradual change from oceanic conditions of sedimentation to continental. This series has only been found near the mouths of the east bank wadis. The Upper Series (Villafranchian) is represented by coarse alluvium in isolated patches on both banks of the Nile on the highest erosional surfaces at +160 to 200 meters elevation above the valley bottom of the paleo-Nile.

The Quaternary fill $\left(Q_{1}\right.$ to $\left.Q_{4}\right)$ is exclusively alluvial and records the encroachment of semi-arid conditions.

\section{REFERENCE}

Chumakov, I. S., 1967. Pliocene and Pleistocene deposits of the Nile Valley in Nubia and Upper Egypt (in Russian). Acad. Science, U.S.S.R., Geol. Institute Trans., Moscow. 170,5 .

\footnotetext{
${ }^{1}$ Summary of a paper read by the author on December 29,1970 at the Moscow Society of Naturalists. Translated into English by T. A. Sofiano.
} 


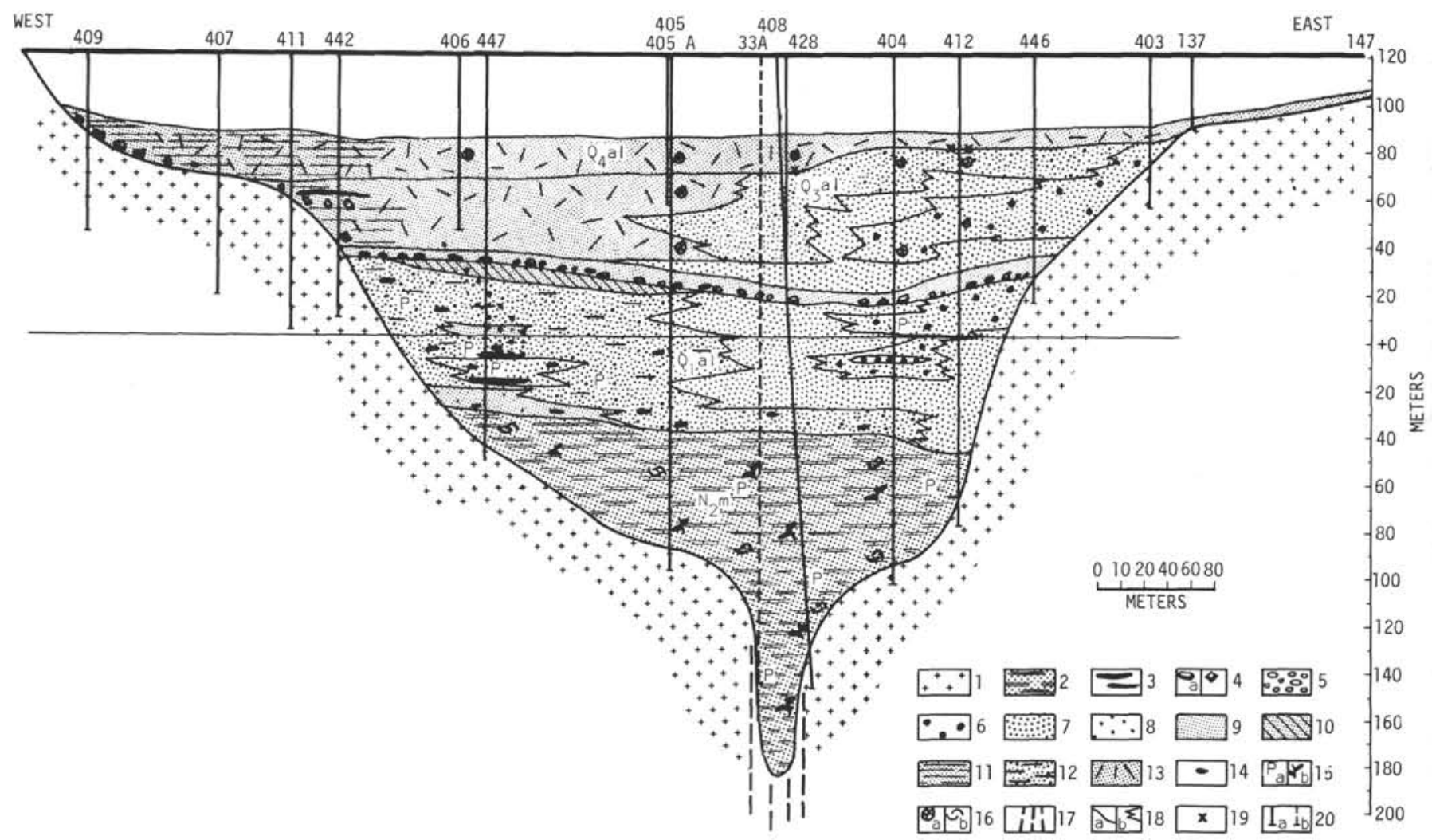

Figure 1. Geological cross-section from boreholes of the Upper Nile Valley south of the Aswan Dam. Legend: (1) rocks of crystalline basement (gneiss and granite); (2) clay with layers of sand and sandy loam; (3) clay lenses in sand; (4a) boulders; (4b) blocks and fragments; (5) pebbles; (6) gravel; (7-13) sands; (7) coarse sand; (8) medium sand; (9) fine sand; (10) sand with thin layers of soil and remains of roots; (11) clayey sand;(12) sand with interbedded clay and loam; (13) micaeous sand; (14) phosphate concretions; (15a) pyrite; (15b) plant remains; (16a) mollusc shells; (16b) ostracode caprices; (17) faults directed along dikes of bostonite; (18a) stratigraphic boundary; (18b) lithologic boundary; (19) archeologic finding; (20a) drillholes; (20b) drillholes projected to the geological profile. Formation identification:

$\mathrm{N}_{2}^{1} \mathrm{~m} \quad$ Siena suite - marine (Lower Pliocene)

$\mathrm{Q}_{1}$ al Kundi Suite - alluvial (Lower Pleistocene)

$\mathrm{Q}_{2} \mathrm{al} \quad$ Shellal Suite - alluvial (Middle Pleistocene)

$\mathrm{Q}_{3}$ al Lower Godingo Suite - alluvial (Upper Pleistocene)

$\mathrm{Q}_{4}$ al Upper Godingo Suite - alluvial (Holocene) 


\title{
44.4. LATE TERTIARY CHANNEL SYSTEM IN NORTHERN LIBYA AND ITS IMPLICATIONS ON MEDITERRANEAN SEA LEVEL CHANGES
}

\author{
F. T. Barr and B. R. Walker, Oasis Oil Company of Libya, Inc., Tripoli, Libya
}

\begin{abstract}
A large fossil drainage system of probable upper Miocene age is recognized along the northeastern flank of the Sirte Basin, northern Libya. The main channel has been traced for about 150 $\mathrm{km}$ eventually being lost under the sarir, just south of Qasr as Sahabi. It has cut into middle Miocene limestone to a depth of over 1300 feet. In this region the surface is near present sea level.

It is postulated that the Sahabi drainage system is the result of an abrupt drop in Mediterranean sea level of at least 1300 feet, and probably more than 2000 feet, during the late Miocene. During the early Pliocene, the sea returned to a level about the same as, or a little less than, that just prior to the late Miocene regression.

Other possible late Miocene drainage systems have been recorded in eastern Libya and the western Desert of Egypt; these may be related to the same sequence of late Tertiary events that affected a great portion of the eastern Mediterranean region.

These Neogene geomorphic features of northeastern Africa, which have long been a perplexing problem, now fit well into an hypothesis which accommodates much of the new data obtained from drilling beneath the floor of the Mediterranean Sea.
\end{abstract}

\section{INTRODUCTION}

Geophysical crews prospecting for oil along the eastern margin of the Sirte Basin, northern Libya, during the late 1960 's, experienced severe velocity problems in the upper 1000 to 2000 feet of surface sediments. Seismic velocities often changed abruptly in this shallow sequence indicating rapid lithologic changes. These sharp velocity changes sometimes coincided with a dry drainage system that occasionally could be observed on the desert surface. It was then recognized that this ancient drainage system, which was of considerable magnitude, was affecting seismic surveys in this area much more than would normally be expected.

A program was initiated to drill a number of shallow holes in this area down to maximum depths of about 920 feet to solve local "weathering" problems, including the definition of the channel system. Stratigraphic and geophysical information derived from this program aided in recognizing the main erosional channels in several areas. However, the heterogeneity of strata and magnitude of the drainage system required a method of closer and deeper control for adequate definition of the principal channels. This was supplied by a refraction crew whose activities were coordinated with those of the shallow hole program.

Information from this program, supplemented with data from field and wildcat wells, has shown the presence of a major late Tertiary fossil drainage system extending for tens of miles that would appear to have significant implications regarding the Neogene history of central Libya and eastern Mediterranean.

\section{DESCRIPTION OF CHANNEL SYSTEM}

This channel system is recognized along the northeastern flank of the Sirte Basin between latitude $29^{\circ}$ to $30^{\circ}$ North, and longitude $20^{\circ} 45^{\prime}$ to $22^{\circ}$ East. Within this area, the closeness of the control used to define this system varies considerably. In a few cases, closely spaced series of holes have been drilled across the main channel. In others, and especially to the south, control data become sparse and sometimes for many miles the channel is only defined by a single hole together with the surface expression of the drainage system.

Our knowledge of the total extent of this fossil drainage system is obviously fragmentary. The available data indicate, however, that the main channel runs in a northwest direction for over $100 \mathrm{~km}$, then in a westerly or southwesterly direction for over $50 \mathrm{~km}$, and eventually it becomes lost under the sarir about $20 \mathrm{~km}$ south of Qasr as Sahabi. The main drainage course is referred to as the Sahabi channel. A large tributary joins the main channel about $50 \mathrm{~km}$ southeast of Qasr as Sahabi after having run due west for at least $45 \mathrm{~km}$. Because of the magnitude of the recognized portions of this system, it is suspected by the authors that this drainage may extend a much greater distance to the south.

On the accompanying sketch map (Figure 1), the channels are illustrated as being rather straight. In areas of closest control there is a suggestion that they may have a slightly more sinuous nature, probably being influenced by the gentle topography encountered on the middle Miocene limestone surface. However, the drainage system appears youthful with no indications of meandering. 


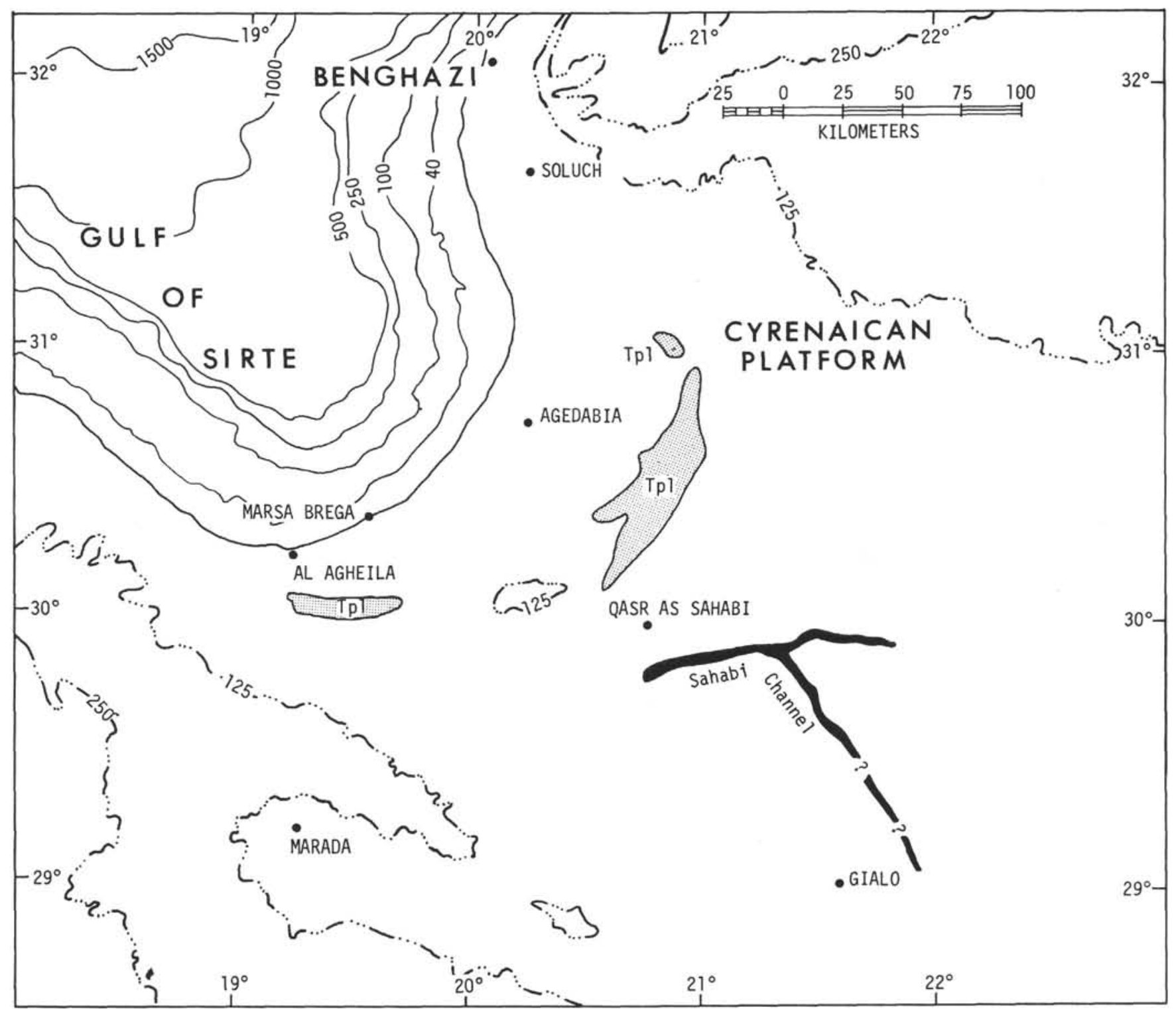

Figure 1. Map of north-central Libya showing location of Sahabi channel system and distribution of Pliocene (Tpl) outcrops. Topographic contours are in feet; bathymetric contours are in meters.

The main channel is steep-sided with a maximum depth greater than the 920 feet of the deepest holes drilled. None of the deep wildcat wells in this area were located over the deepest part of the main channel. However, a maximum depth for the channel in excess of 1300 feet was calculated from the seismic shallow refraction surveys (Figure 2). This depth is judged to be fairly accurate because when nearby holes penetrated the shallower subsidiary channel the drill depths and geophysically calculated depths agreed closely. The breadth of the Sahabi channel appears to vary from less than a kilometer to a maximum of over $5 \mathrm{~km}$.

In addition to the fairly well delineated Sahabi channel, fragmentary seismic data indicate a similar filled channel to the northwest, nearer the apex of the Gulf of Sirte. This channel appears to have a maximum depth of 1800 to 2000 feet. Although it is not completely documented, we believe it is the northwestern extension of the Sahabi channel.
The Sahabi channel system has been cut into a sequence of middle Miocene carbonate rocks which is exposed at the surface over much of this area. These rocks usually consist of well-lithified, highly fossiliferous calcarenite and dolomite. Thin interbeds of dark shale and rare gypsum are also present. A diverse foraminiferal fauna which includes numerous specimens of Borelis melo (Fichtel and Moll) is usually present. This species is characteristic of much of the widespread middle Miocene carbonate rocks of Cyrenaica. This sequence is assignable to the $\mathrm{Al}$ Jaghbub Formation (Bellini, 1969) and is also similar lithologically and paleontologically to the middle Miocene Regima Formation of northern Cyrenaica (Kleinsmeide and van den Berg, 1968) and the Marmarica Limestone of the western Desert of Egypt (Said, 1962a, 1962b).

The sediments that fill the channels are quite distinct from the middle Miocene host rock. These sediments 

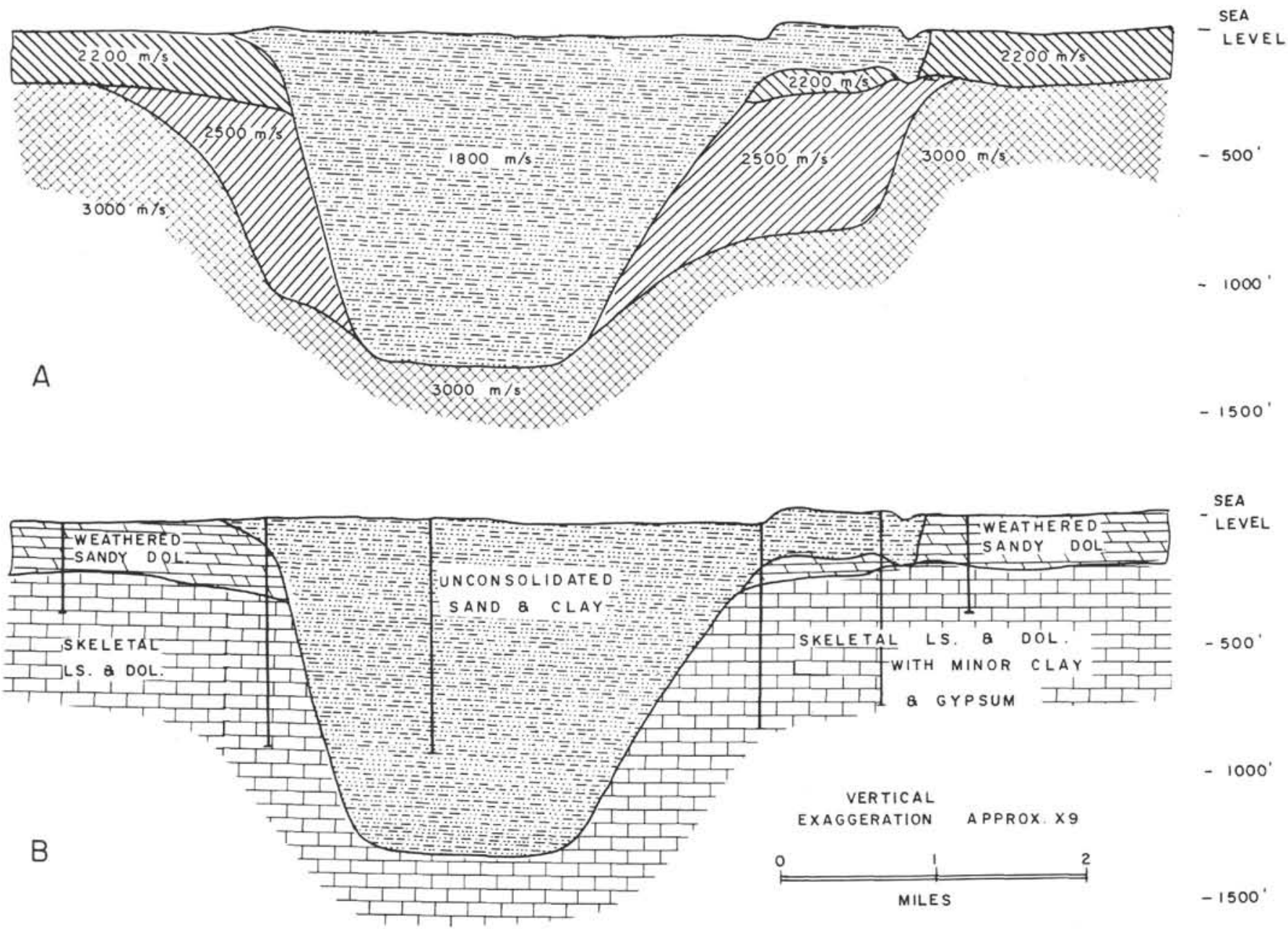

Figure 2. Slightly oblique cross sections across the main channel southeast of Qasr as Sahabi. (A) Refraction profile across channel showing velocities in meters per second of channel fill $(1800 \mathrm{~m} / \mathrm{s})$, weathered zone $(2200 \mathrm{~m} / \mathrm{s})$, partially leached bed rock $(2500 \mathrm{~m} / \mathrm{s})$ and unaltered bed rock $(3000 \mathrm{~m} / \mathrm{s})$. (B) Lithologic profile across the same traverse based on a series of shallow bore holes supplemented by seismic data.

consist of unconsolidated quartz sand, silt, and clay. The sands and clays are equiproportional, although samples may vary from entirely sand to completely clay. The sands usually are uncemented although they are accompanied by some clay matrix. Also, they vary widely from very coarse to fine grained, and from rounded to angular. Some of the more spherical quartz grains have been frosted. Sorting may also vary considerably, although moderate to well-sorted sands in the fine to medium range predominate. Mica and carbonate grains, although usually rare, are locally common. Rare grains of feldspar, glauconite (derived), and dark minerals are recorded. The clays are soft, non-calcareous, and occasionally pyritic.

The channel fill sediments are usually unfossiliferous except for an occasional ostracod or mollusc fragment. A few foraminifera have been recovered, but they are extremely worn and, along with the rare glauconite grains, are considered derived from the middle Miocene host rock.

The nature of these sediments suggests that they were deposited under non-marine, fluvial conditions. A possible source might be the continental Tertiary beds at a considerable distance to the southeast. There also appears to be some windblown material incorporated in this deposit.

\section{LATE TERTIARY HISTORY OF NORTHEASTERN AFRICA}

In order to evaluate the possible events that may have been responsible for the Sahabi channel system, the late Tertiary history of northeastern Africa is briefly reviewed.

\section{Miocene (pre-Messinian)}

Marine deposits of middle Miocene age are widespread across much of the northern portions of Tunisia, Libya, and Egypt (Figure 3). In general, this was a time of renewed transgression along the southeastern coast of the Mediterranean. After the initial transgression, stable conditions prevailed over much of northern Cyrenaica and the western desert of Egypt and resulted in the deposition of rather uniform shallow marine carbonates over a broad area.

In Tunisia, local orogeny was important and resulted in the formation of a number of small basins with somewhat different histories. At the end of the Oligocene, most, if not 


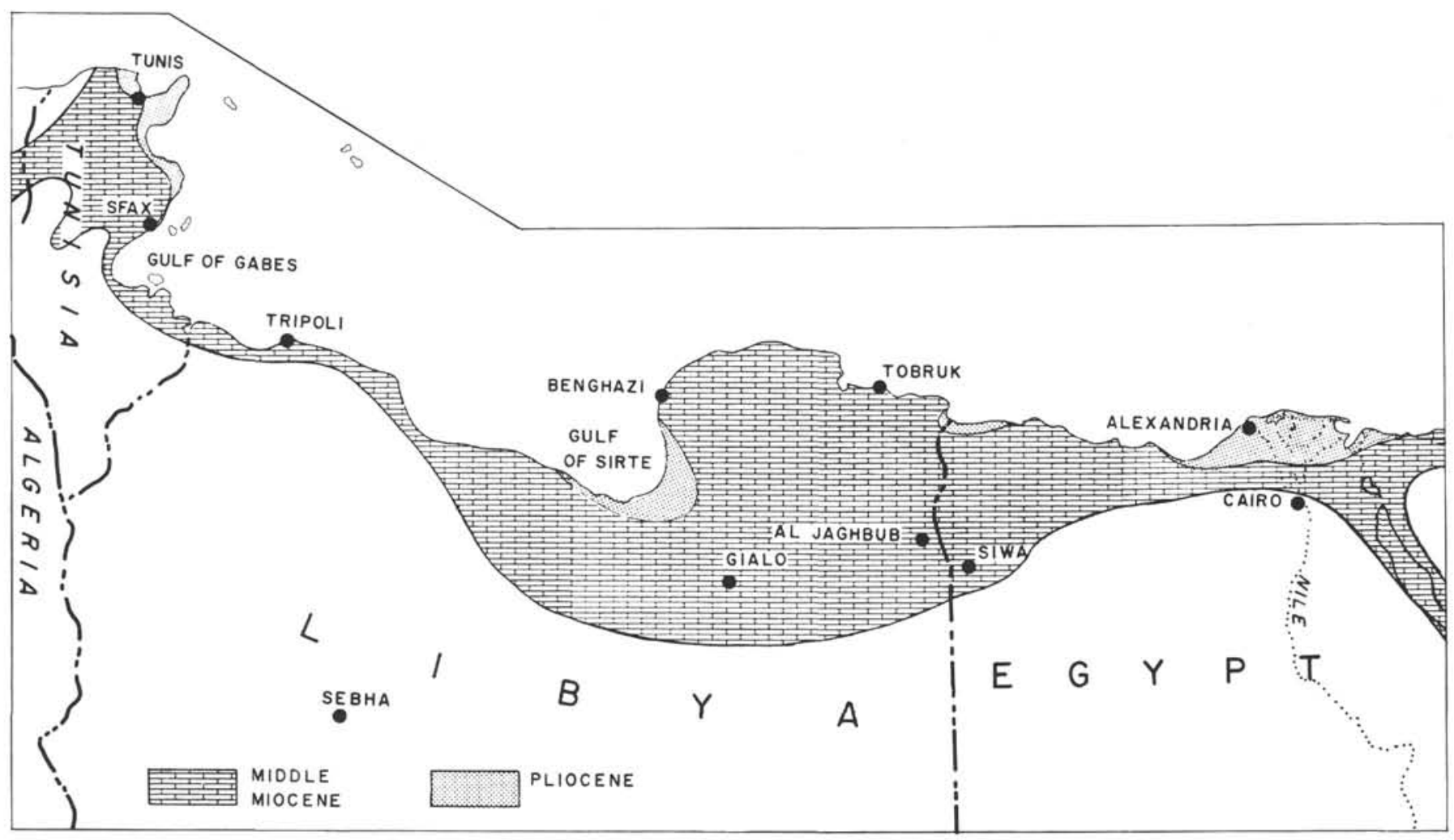

Figure 3. Paleogeographic sketch map showing distribution of the Middle Miocene and Pliocene seas in northeastern Africa.

all, of Tunisia was briefly emergent. Then during the early Miocene, a marine transgression from the east or northeast commenced and continued into the Vindobonian. By mid-Miocene time, much of northeastern and central Tunisia was inundated by marine seas. Southern and northwestern-most Tunisia remained emergent. These Vindobonian sediments consist mainly of shallow marine gray shales and marls with some thin sandstone, limestone, and occasional lignite beds. This sequence is called the Oum Douil Formation (Burollet, 1967) and attains a maximum thickness in excess of 1000 feet.

In Libya, the Miocene was also a time of transgression following a brief emergence at the end of the Oligocene, at least in the coastal areas of Cyrenaica and Tripolitania. Sedimentation across the Oligocene-Miocene boundary in the deeper parts of the Sirte Basin may have been uninterrupted. However, there is an unconformable relationship along the margins of the basin. Middle Miocene sediments are present in Tripolitania only along the coastal area; on the Jefara. In the Sirte Basin, which consists of differentially subsiding horsts and grabens, the Miocene sequence varies greatly in lithofacies and thickness. In the deeper and more rapidly subsiding troughs, thick sequences of dark shales containing an abundant planktonic foraminiferal assemblage (Berggren, 1969) are present. On the shoaler horst blocks, shallow carbonates, including coralline deposits, usually prevail. In northeastern Libya, uniform deposits of shallow marine chalky calcarenites, containing the diagnostic foraminifer Borelis melo, cover much of the Cyrenaica platform. These limestones, which are assigned to the Al Jaghbub and Regima Formations in
Libya, extend across into the western desert of Egypt as the Marmarica Limestone. Bellini (1969) records a thickness of 115 meters for the Al Jaghbub Formation in its type area and Said $(1962$ b, p. 203, 204) reports similar thicknesses for the Marmarica Limestone in the western desert.

In the Cairo-Suez area of Egypt, Miocene rocks again represent a marine transgression after a brief emergence at the end of Oligocene. The middle Miocene is faunally and lithologically similar to the Marmarica Limestone of the western desert (Said, 1962b) and represents a continuity of similar chalky calcarenite deposition over several hundred miles along the southeastern coast of the Mediterranean.

The Gulf of Suez, like most of the rest of northeastern Africa, was emergent during the Oligocene and was again invaded by Teythian seas during the early Miocene. Miocene seas deposited in this embayment over 2900 meters of deep water marls and shales, which are called the Globigerina Marls. Most of this sequence is early Miocene in age, however, the upper part of the Globigerina Marls contrains Orbulina universa d'Orbigny and is considered middle Miocene in age. Following deposition of the Globigerina Marls, the flow of water into the Gulf of Suez became restricted, converting the gulf into a hypersaline basin (Barr, 1964, p. 138). A thick sequence of evaporites, consisting of alternating beds of anhydrite, shale, marl, and some dolomite, was deposited in this restricted basin. This sequence varies greatly in thickness throughout the Gulf of Suez area, in places attaining a thickness of several thousand meters. These sediments appear to conformably overlie the Globigerina Marls and in the past have usually been considered middle Miocene in age, although with little 
paleontologic evidence. Considering the new DSDP data on the middle and upper Miocene of the eastern Mediterranean, this age assignment should be reviewed.

\section{Upper Miocene (Messinian)}

It has long been recognized that the late Miocene was a time of regression in northern Africa, although the extent of this regression may not have been fully realized. There are, however, a number of reports of marine upper Miocene rocks in Libya and adjacent areas. It is the objective of this section to review some of these records.

In Tunisia, widespread emergence has often been recorded at the end of Miocene time (Burollet, 1956, 1967). Continental deposits of apparent upper Miocene age overlie Vindobonian sediments over a large portion of eastern Tunisia.

There have been several records of marine upper Miocene (Messinian) rocks in Libya. Berggren (1969) recorded several hundred feet of unconsolidated sands and sandy calcarenites overlying deep-water, open sea, Tortonian deposits in the northern Sirte Basin, which he tentatively assigned to the Messinian. These sediments contain a sparse microfauna consisting mainly of Elphidium, Ammonia, Asterigerina and Amphistegina. Although these forms occur in the late Miocene, they are not diagnostic of that age and could just as well be from the Pliocene or Pleistocene.

Another report of upper Miocene is recorded on the USGS geologic map of Libya (Conant and Goudarzi, 1964). It shows two main patches that are considered to be marine upper Miocene. The larger is an east-west band extending from Al Jaghbub to a point just north of Qasr as Sahabi. These sediments, which unconformably overlie the middle Miocene Al Jaghbub Formation, consist mainly of unconsolidated quartz sands with occasional beds of green shale and limestone. De Cesare, Franchino, and Sommaruga (1963) have made a detailed study of these beds and conclude that they are mainly continental deposits of Pliocene to Quaternary age. In a single sample, a few shallow marine foraminifera, including Ammonia, were recovered. It is uncertain if this represents a brief marine incursion, or alternatively, whether these foraminifers may have been derived from older beds. Nevertheless, these beds, which are given the name Garet Uedda Formation, are considered Pliocene or younger. It is probable that the sands considered by Berggren (1969) to be Messinian in the northern Sirte Basin are in part or wholly equivalent to the Garet Uedda Formation.

We have also had the opportunity to examine these same sediments which were penetrated by many shallow holes drilled north and east of Qasr as Sahabi. A few derived foraminifera were recovered from these sediments, but, as far as could be determined, the entire sequence, which consists predominantly of unconsolidated quartz sand, appeared to have had a continental origin.

In an early study of the Tertiary of Cyrenaica, Stefanini (1923) recorded the occurrence of upper Miocene (Pontian) rocks in several localities in northern Cyrenaica and Sirtica. These age assignments were made with considerable reservation, being based mainly on analogy with gypsiferous sulfur-bearing strata in Sicily. However, Desio (1935) disagreed with the late Miocene age attributed to these beds and was able to demonstrate that most of them were middle Miocene (Vindobonian) in age. Desio, however, thought upper Miocene strata did occur in a few restricted areas. He considered a sandy limestone found near Soluch and the limestone of Regima to be upper Miocene as they contained several fossils in common with a reported upper Miocene deposit found near the head of the Gulf of Suez. As no marine upper Miocene is now recognized in the Suez area, the age assignment for the Soluch limestone is questionable and a middle Miocene age has been demonstrated for the limestone at Regima (Kleinsmeide and van den Berg, 1968).

There have been several other reports of upper Miocene deposits in Libya, however, in each case there was no definitive paleontologic evidence for the determination. Although it remains impossible to disprove every report of possible marine Messinian sediments in Libya, evidence has yet to be presented that they do, in fact, occur. It is therefore suggested by the authors that it is quite probable that there are no marine Messinian sediments in Libya.

Marine Messinian strata do not appear to be present in the Western Desert of Egypt. Said (in Bellini, 1969, p. 181) states that marine carbonates of Pliocene age unconformably overlie the middle Miocene Marmarica Limestone. Mansour, Barkat, and Abdel Hady $(1969$, p. 839) record lower Pliocene sediments unconformably overlying the middle Miocene Marmarica Limestone along the Gulf of Salum in northwestern-most Egypt. Omara and Ouda (1969) also report Pliocene sediments unconformably overlying the middle Miocene in a well just west of Alexandria.

In the Cairo-Suez area, 20 meters of non-marine grits and gravels of probable upper Miocene age overlie the marine middle Miocene. These beds are unfossiliferous, but are similar to strata in the northern Gulf of Suez area where upper Miocene fresh-water snails have been reported (Said, 1962b).

\section{Pliocene}

After the major regression that brought the Miocene Epoch to a close, the Pliocene returned the Mediterranean Sea to some of the coastal areas of northeastern Africa (Figure 3).

During the Pliocene, most of Tunisia was emergent, with the sea occupying only a narrow band along the present eastern and northeastern coast. Cape Bon and the Bizerte Lake area received the greatest accumulation of sediments where fossiliferous clays and marls have an average thickness of over 300 meters.

There have been few reports of marine Pliocene strata in Libya. Desio (1935) recorded the occurrence of shallow marine sands and clays in the northern Sirte Basin which, although his paleontologic evidence was inconclusive, he considered Pliocene in age. On the geologic map of Libya (Conant and Goudarzi, 1964), three patches of marine and continental Pliocene deposits are shown (which include Desio's localities) located in an arc along the southeastern shore of the Gulf of Sirte (Figure 1).

Therefore, although the evidence is far from definitive, there is an indication that the Gulf of Sirte may have 
extended a short distance past its present shoreline during the Pliocene and covered an area south and east of $\mathrm{Al}$ Agheila and Agedabia. The rest of Libya was probably emergent.

Pliocene seas occupied the coastal area of the western Desert. In an important paper on this subject, Mansour, Barakat, and Abdel Hady (1969) record 78 meters of mainly sandy limestone that unconformably overlie the Marmarica Limestone along the southwestern shore of the Gulf of Salum and document its large foraminiferal fauna. They assign this sequence to two planktonic zones of the Lower Pliocene, the Sphaeroidinellopsis spp. Acme-zone and the Globorotalia margaritae Total-range-zone.

Further to the east, Omara and Ouda (1969) described a diverse foraminiferal fauna from 150 feet of soft clays and shales of Pliocene age that were penetrated by the Burg el Arab Well about $45 \mathrm{~km}$ west of Alexandria. This sequence rests unconformably on middle Miocene limestone.

In the subsurface of the Nile Delta, Viotti and Mansour (1969) recognized four planktonic zones which they considered belonging to the Miocene. They are: the Globigerina nilotica Zone, the Globigerina nepenthes Zone, the Sphaeroidinellopsis seminulina grimsdalei Zone, and the Globorotalia fohsi peripheroronda Zone. An unconformity is present separating the lowermost zone from the upper three units. The oldest zone, the Globorotalia fohsi peripheroronda Zone, is middle Miocene in age. However, in a re-evaluation of this work Mansour et al. (1969) now consider the upper three zones as lower Pliocene. The evidence therefore, indicates that an open sea planktonic facies of lower Pliocene age unconformably overlies an open sea facies of the middle Miocene with the upper Miocene being represented by a period of emergence.

\section{ORIGIN OF SAHABI CHANNEL}

In summary, there is a large-scale drainage system cut at least 1300 feet into middle Miocene limestone on the northeastern border of the Sirte Basin. The area of the drainage system is a flat low-lying region, much of which is less than 100 feet above sea level; some portions near the system's western extremity are at or a little below sea level. In general, this area does not appear to have been very much affected by Neogene tectonics.

There are two alternative hypotheses for the origin of the Sahabi channel system: one relies on the raising and lowering of the land area; the other utilizes a lowering and rising of the sea.

The first hypothesis invokes the following sequence of events. During post-middle Miocene times, a large portion of the Cyrenaican platform would have been raised epirogenically over 1300 feet above sea level (or above its present elevation). A large drainage system would rapidly develop, cutting sharply into the flat-lying middle Miocene limestone. This system would empty into the Mediterranean about at the apex of the present Gulf of Sirte. Following this brief period of emergence and erosion, the Cyrenaican platform would then be lowered the same amount that it had just been raised. Therefore, in a relatively short interval of time, the Cyrenaican platform would have been elevated at least 1300 feet, probably quite a bit more, and lowered the same amount. After the lowering, the drainage system would have been filled by fluvial and some eolian sediments.

The second, alternate hypothesis envisages great changes in the Mediterranean sea level. During post-middle Miocene time, there was a sudden drop in the sea level of the Mediterranean of at least 1300 feet, or probably considerably more since the Sahabi channel, where it is observed, would still have many miles to run before reaching the Mediterranean with a reduced sea level. The drainage would have been rapidly eroded into the middle Miocene limestone during this time of Mediterranean shrinkage. Then with equal rapidity, the sea level of the Mediterranean would rise returning to its former (and present) level. The drainage system, then below grade, would be filled with fluvial-eolian sediments.

Both hypotheses demand dramatic movements of land or sea. However, there are several lines of evidence that support the second hypothesis, which is favored by the authors:

(1) The area of this drainage system does not appear in other respects to have been tectonically active during the Neogene.

(2) A great lowering of the eastern Mediterranean sea level would produce other large scale, widespread drainage features. There have been several records of other, possibly related systems. Di Cesare, Franchino, and Sommaruga (1963, p. 38) describe a major fossil drainage pattern cut into the $\mathrm{Al}$ Jaghbub Formation located about $100 \mathrm{~km}$ southeast of the Sahabi channel, an area that presently receives very little rainfall. The drainage ran from northwest to southeast, although they state that it was sometimes reactivated in the opposite direction. These authors were able to date that drainage as post-middle Miocene to pre-Pleistocene. Bellini (1969, p. 167) also comments 'on this same ancient hydrographic system between Al Jaghbub and Gialo. Another ancient drainage system observed on aerial photographs has been recorded by Squyres and Bradley (1964, p. 101) in the Western Desert of Egypt. In addition, Chumakov (1967), using material from numerous bore holes, has documented a large channel in the Nile Valley of upper Egypt. This channel was cut into igneous bed rock by an ancestral Nile River 200 to 300 meters below the Nile's present level. The basal sediments filling this ancient channel consist of gray, montmorillonitic clays with thin lenses of fine-grained, micaceous sands and sandy loams that are rich in plant detritus. A uniform suite of authigenic minerals are present, including glauconite, zeolite, pyrite, and siderite. The sands are partially cemented by secondary calcite. Rare ostracods belonging to the genera Cypridea, Cyprinotus, Limnocythere, Eucypris, and Candoniella were recovered, which suggest a brackish environment of deposition and an early Pliocene age for the lower-most channel fill. Chumakov believes this channel to have been cut during late Miocene time, resulting in the formation of an enormous marine estuary in the Nile Valley during the early Pliocene.

(3) DSDP Leg 13 has added substantial support for the sea level lowering and rising hypothesis with the discovery of upper Miocene halite and other evaporites overlain by normal marine lower Pliocene sediments at various locations in the Mediterranean. Normal marine middle 
Miocene limestones and sandstones were also sampled in the eastern Mediterranean. Together, they suggest the same chronological sequence of environmental conditions that is indicated by the Neogene succession along the coastal area of northeastern Africa.

\section{Age of Sahabi Channel}

On the basis of direct paleontologic evidence, it can only be said that the cutting of the Sahabi channel took place during post-middle Miocene time. However, a regional review of the Miocene and Pliocene sediments of Libya and adjacent countries gives strong support to an upper Miocene age for this drainage system. Middle Miocene sediments were widespread across northeastern Africa. An abrupt regression then took place during the late Miocene, leaving Tunisia, Libya, and Egypt emergent and subject to subaerial erosion. This was followed by a lower Pliocene transgression which, however, only reached the coastal area of these countries.

This same sequence of events is recognized in the DSDP data in presently deep areas of the Mediterranean.

Further support for an upper Miocene age come from the observations of Di Cesare, Franchino and Sommaruga (1963, p. 38), who date the drainage system southeast of the Sahabi channel as upper Miocene or Pliocene. They demonstrate that it is post-Al Jaghbub Formation and pre-Garet Uedda Formation. As there is some evidence for a Pliocene age for some of the Garet Uedda Formation, this might suggest an upper Miocene age for this fossil drainage system.

\section{CONCLUSIONS}

The Sahabi channel which extends for about $150 \mathrm{~km}$ or more, is one of several late Tertiary drainage systems recognized in eastern Libya and western Egypt. This system has cut over 1300 feet below sea level into middle-Miocene rocks, probably during late Miocene time. It is suggested that a sudden drop in Mediterranean sea level of considerably more than 1300 feet was responsible for this deep drainage erosion. This was followed by a sudden rising of sea level during the early Pliocene back to a level perhaps a little lower than that just before the regression. This resulted in the Sahabi channel being below grade and therefore rapidly filled with fluvial and some eolian sediments.

The geomorphic observations in northeastern Africa suggest a series of widespread events that agree closely with those interpreted from data gained during drilling in the Mediterranean. It is suggested that the Gulf of Sirte might well provide a fruitful area for future oceanographic studies in relation to these observations in northern Libya. An investigation of the southeastern margin of the gulf to determine if evidence of a submerged drainage system is present and an examination of the east-central gulf for the possible occurrence of upper Miocene fans (possibly interdigitating with an evaporite sequence) would be of interest and might add important information to our knowledge of the Messinian paleogeography of the eastern Mediterranean area.

\section{ACKNOWLEDGMENTS}

The authors thank D. D. Skeels who examined the lithology in many of the shallow holes that penetrated the Sahabi channel system and Coy $\mathrm{H}$. Squyres who reviewed the manuscript and offered many valuable suggestions. Oasis Oil Company of Libya has granted permission to publish this paper.

\section{REFERENCES}

Barr, F. T., 1964. Geology of the Gulf of Suez Area. In Guidebook to the Geology and Archaeology of Egypt. F. A. Reilly (Ed.). Petrol. Explor. Soc. Libya. 123. Tripoli.

Bellini, E., 1969. Biostratigraphy of the "Al Jaghbub (Giarabub) Formation" in Eastern Cyrenaica (Libya). Proc. 3rd African Micropal. Colloquium. 165, pl. 1. Cairo.

Berggren, W. A., 1969. Biostratigraphy and Planktonic Foraminiferal Zonation of the Tertiary System of the Sirte Basin of Libya, North Africa. Proc. 1st Internat. Conf. on Planktonic Microfossil. 104. Geneva.

Burollet, P. F., 1956. Contribution a l'étude stratigraphique de la Tunisie Centrale. Ann. des Mines et de la Geol. 18 , 350 p. pls. 1-22. Tunis.

1967. Tertiary Geology of Tunisia. In Guidebook to the Geology and History of Tunisia. L. Martin (Ed.). Petrol. Explor. Soc. Libya. 215. Tripoli.

Chumakov, I. S., 1967. Pliocene and Pleistocene deposits of the Nile Valley in Nubia and Upper Egypt (in Russian). Acad. Science U.S.S.R. Geol. Institute, Trans. 170, p. 5. Moscow.

Conant, L. C. and Goudarzi, G. H., 1964. Geologic Map of Kingdom of Libya. U. S. Geol. Survey, Misc. Geol. Inv., Map I-350A.

Desio, A., 1935. Missione scientifica della Reala Accademia d'Italia a Cufra (1931-IX); vol. I, Studi geologici sulla Cirenaica, sul Deserto Libico, sulla Tripolitania e sul Fezzan Orientali. Reale Accad. d'Italia, Viaggi di Studio ed Esploranzioni. 1, pls. 1-6, map, Rome.

Di Cesare, F., Franchino, A. and Sommaruga, C., 1963. The Pliocene-Quaternary of Giarabub Erg Region. Proc. First Sharan Symposium. Rev. de l'Institut Francais du Petrole. $18(10,11), 30$.

Kleinsmeide, W. F. J. and van den Berg, N. J., 1968. Surface Geology of the Jabal al Akhdar, Northern Cyrenaica, Libya. In Geology and Archaeology of Northern Cyrenaica, Libya. F. T. Barr (Ed.). Petrol. Explor. Soc. Libya. 115, 2 pls., geol. map, Tripoli.

Mansour, A. T., Barakat, M. G. and Abedel Hady, Y. el S., 1969. Marine Pliocene Planktonic Foraminiferal Zonation South-east of Salum, Egypt. Riv. Ital. Paleont. 75 (4), 833. pls. 59-61.

Omara, S. and Ouda, K., 1969. Pliocene Foraminifera from the sub-surface rocks of Burg el Arab Well No. 1, Western Desert, Egypt. Proc. 3rd African Micropal. Colloquium. 581,5 pls., Cairo.

Said, R., 1962a. Das Miozän in der westlichen Wüste Ägyptens. Geol. Jb. 80, 349, pls. 30, 31 .

1962b. The Geology of Egypt. (Elsevier Publ. Co.). 377 pp., 10 pls., 17 tables, Amsterdam, New York.

Squyres, C. H. and Bradley, W. B., 1964. Notes on the Western Desert of Egypt. In Guidebook to the Geology and Archaeology of Egypt. F. A. Reilly (Ed.). Petrol. Explor. Soc. Libya. 99, pl. 1, Tripoli.

Stefanini, G., 1923. Fossili terziari della Cirenaica. Paleontogr. Italica. 27, 101. Pisa. 
Viotti, C. and Mansour, A., 1969. Tertiary Planktonic Foraminiferal Zonation from the Nile Delta, Egypt, U.A.R., Part I: Miocene Planktonic Foraminiferal Zona- tion. Proc. 3rd African Micropal. Colloquium. 425, pls. 1-5. Cairo.

\title{
44.5. THE EUSTATIC HYPOTHESIS AND THE PRE-PLIOCENE CUTTING OF THE RHONE VALLEY
}

\author{
Georges Clauson, Laboratoire de G'eographie Physique, Universite d'Aix-Marseille, 13, Aix-en-Provence, France
}

The finding of an extensive layer of evaporites in the deep drillings in the Mediterranean revives a new interest in the hypothesis of a temporary isolation of this sea at the end of the Miocene. Since this idea has already received support from the interpretation of boreholes within the Rhone Valley in southern France, I have been invited to first trace the history of this hypothesis, and then examine how it provides a unique solution to a number of problems of continental paleogeography.

\section{BACKGROUND AND HISTORY OF THE "DENIZOT HYPOTHESIS"}

The eustatic hypothesis is far from being a new idea. Ever since Depéret (1895), it has been entertained by a number of authors. However, they always relied on a worldwise cause for sea-level change without ever really commenting on its origin.

It was Denizot who first offered an explanation for the extraordinary amplitude of the regression which was believed to have occurred in the Mediterranean basin. In a paper published in 1952 on the Pliocene in the Rhone
Valley, he explicitly developed the concept of an isolation of the Mediterranean. Consequently, I refer to it here as the "Denizot hypothesis." The original text is worth quoting: ${ }^{1}$

"Il y eut une régression de la fin du Miocène, d'une très grande généralité, qu'on reconnait aussi sur le versant atlantique: c'est un tel system de vallées que la mer pliocène devait envahir, à l'embouchure actuelle de la Loire. Mais en outre, pour ce qui est de la Méditerranée à ce moment, les détroits espagnols et marocains s'étant fermés, et avant que ne s'ouvre celui de Gibraltar, il s'est produit un séparation complète de cette mer. Elle s'est alors réduite à une lagune, et a évolué indépendamment suivant les conditions climatiques: il y eut baisse de son niveau, en se bordant d'une frange littorale où peuvent singulièrement voisiner étangs saumâtres et lagunes de concentration. Telle est maintenant, en moins grand, la Mer Caspienne.

A la phase suivante s'ouvre le détroit de Gibraltar: la Méditerranée reprend le caractère de mer normale et transgresse sur ses côtes en même temps que fait l'Altantique. Cette mer envahit alors le réseau fluvial qui venait de se creuser et notamment la vallée du Rhône, objet de la

\footnotetext{
${ }^{1}$ Editor's translation-

"There was a regression of the sea at the end of the Miocene over a widespread area which was observed also on the Atlantic coast: it is such a system of valleys that the Pliocene sea had to invade to the mouth of the Loire itself. With the connecting passageways across Spain and Morocco closed and the Gibraltar Strait not yet opened, the Mediterranean at that moment became completely isolated. It was subsequently reduced to a lagoon and evolved independently according to climatic influence: there was a drop in sea level such that the bordering coastal fringe became
}

occupied by brackish ponds and saline lagoons. On a smaller scale, the Caspian Sea is such an example.

In the following period the Strait of Gibraltar opened: the Mediterranean took back its normal character and the sea transgressed its coasts at the same time as did the Atlantic. This sea invaded the fluvial network previously incised, in particular the valley of the Rhône which is the object of present study. Other authors have often commented on the various aspects of the Pliocene transgression: its widespread occurrence evoking a raising of the entire surface of the sea-that is an eustatic movement." 
présente étude. Les auteurs ont abondamment commenté les divers aspects de cette transgression pliocène: sa généralité évoque un mouvement d'ensemble de la surface marine, un mouvement eustatique."

As was mentioned, the occurrence of Pliocene deposits at a lower base-level than Miocene formations has caused consternation for all previous authors. Fontannes (1882) first outlined the contours of this marine transgression which would be subsequently called "the Piacenzian ria." He showed the unconformable generalized erosion along the old channel cutting and interpreted the actual setting as a consequence of the tectonic deformations of the terminal Miocene.

The finding of marine Pliocene deposits, with a thickness in excess of 100 meters, in drilling sites located in the Valence plain, led Depéret (1895) to the following conclusion ${ }^{2}$ : “ . . . le fond de la vallée marine pliocène était creusé très en dessous de la vallée actuelle." And he adds: ${ }^{3}$ "Lá Méditerranée pénètre à l'interieur de la vallée du Rhône suivant un trajet remarquablement identique à celui du Rhône actuel. .." Finally, he gives the following interpretation: ${ }^{4}$ " ... sans doute par suite d'un abaissement des lignes de rivages de la mer, de puissants phénomènes de ravinement on entaillé dans la masse du Miocène des vallées identiques, pour la plupart au moins, à nos vallées actuelles." The regression is situated after the orogenic phase of the terminal Miocene (Phase Rodanienne).

We have to wait until 1952 in order to find a statement concerning a correlation between the Mediterranean eustatism and the (temporary) isolation of this basin. This relationship had most likely been suggested to Denizot by the drilling program of the 1950's in Camargue. The deep drillings there revealed an unexpected and very irregular thickness (locally in excess of $1000 \mathrm{~m}$ ) of marine sediments of Pliocene age; the sediments are lying on a very differentiated topography cut by real subaerial canyons (Beaufort et al., 1954).

Taking into account other contemporary wells which had demonstrated the lack of a Neogene thalweg beneath the Rhône straits at Donzere (Figure 1), Denizot limited the influx of the Miocene cutting to the course downstream of Donzere. The marine sediments of Pliocene age located upstream, underneath the Valence plain, were interpreted as a deposit related to a subsiding axis (ombilic de subsidence). All this rendered frail the conviction of Depéret (1895) and of Baulig (1953).

Recent drillings have once more renewed the question. They have been undertaken in the Malataverne sill (located eastwards of the straits of Donzere) and underneath the river bed between Saint-Vallier and Tournon. The first ones discovered the Pliocene clay masked at the surface by the

\footnotetext{
2 "... the bottom of the Pliocene marine valley was incised very much below the present valley."

3 "The Mediterranean penetrated to the interior of the Rhône valley along a course remarkably similar to its present one..."

4 “. ... without doubt as a result of a lowering of the shore line of the sea, powerful gulleying had cut into the Miocene substratum valleys for the most part identical to the present ones."
}

alluvial blankets of Quaternary age, thus demonstrating the passage of the Neogene Rhône through this sill. We can understand why the Donzere wells did not identify the pre-Pliocene thalweg in a location where it never had existed! The second group of wells, beneath the recent alluvium, penetrated the same clays for a thickness of about 80 meters. When terrninated at +45 meters above sea-level, the drillings had not yet reached the metamorphic basement rocks. On the basis of the gradient of the slopes, Mandier (1969) located the pre-Pliocene thalweg some 50 to 100 meters further, or 130 to 180 meters beneath the Rhône valley. This information is very interesting, because up to that time all authors had been thinking that the present day river bed had reached the base of the Neogene cutting.

Numerous data from the boreholes has permitted one to reconstruct with a certain degree of accuracy the physiography of the pre-Pliocene valley (see Figure 2). It turns out to be a continuous and very narrow valley, excavated to a level which is everywhere lower than the present Rhône thalweg. The known outcrops of marine sediments of Pliocene age allow one to follow this canyon all the way for a distance of almost $300 \mathrm{~km}$ from the Mediterranean shore, near Grau du Roi, to Lyon. The point of view expressed by Depéret in 1895 is thus entirely confirmed.

\section{ROLE OF EUSTATIC SEA-LEVEL CHANGE IN THE PRE-PLIOCENE CUTTING OF THE RHÔNE VALLEY}

For a long time, the insufficient number of drilling sites having a deep penetration, and their contradictory results, rendered a synthesis difficult. The more recent interpretations and/or conclusions are not much better than the earlier ones, since they depart with an a priori assumption: some are fixists, others are mobilists.

In order to try to clearly evaluate all facts, it is necessary to not consider a general analysis, but to distinguish between the five major events which characterize the geologic history since Tortonian time. They are as follows:

1) The late Miocene tectonic phases ("Phase Rhodanienne"),

2) The Messinian eustatism,

3) The intra-Pliocene tectonic activity,

4) The post-Pliocene tectonic activity, and

5) The Quaternary glacio-eustatism.

As an example, if we sum the effects of episodes 3 ) and 4), one can convince himself of the possibility of excluding the reality of of episode 2). Since it is necessary to avoid this kind of confusion, we have to select a field of investigation in which such confusion is impossible. The intra-Pliocene tectonic activity is one that involves differential movements affecting the Rhone Valley: the Camargue, the Pujaut trench, and the Valence plain. Contrary to the intra-Pliocene tectonics, the post-Pliocene tectonics are essentially epeirogenetic. All the Rhône Valley downstream has been deformed by subsidence, while the upstream part underwent a general uplift.

In between Lyon and Valence, there is an area which has not been affected by intra-Pliocene deformation. Here, in the straits upstream from Tain-Tournon, we can evaluate the exclusive effects of the post-Pliocene tectonic activity. 


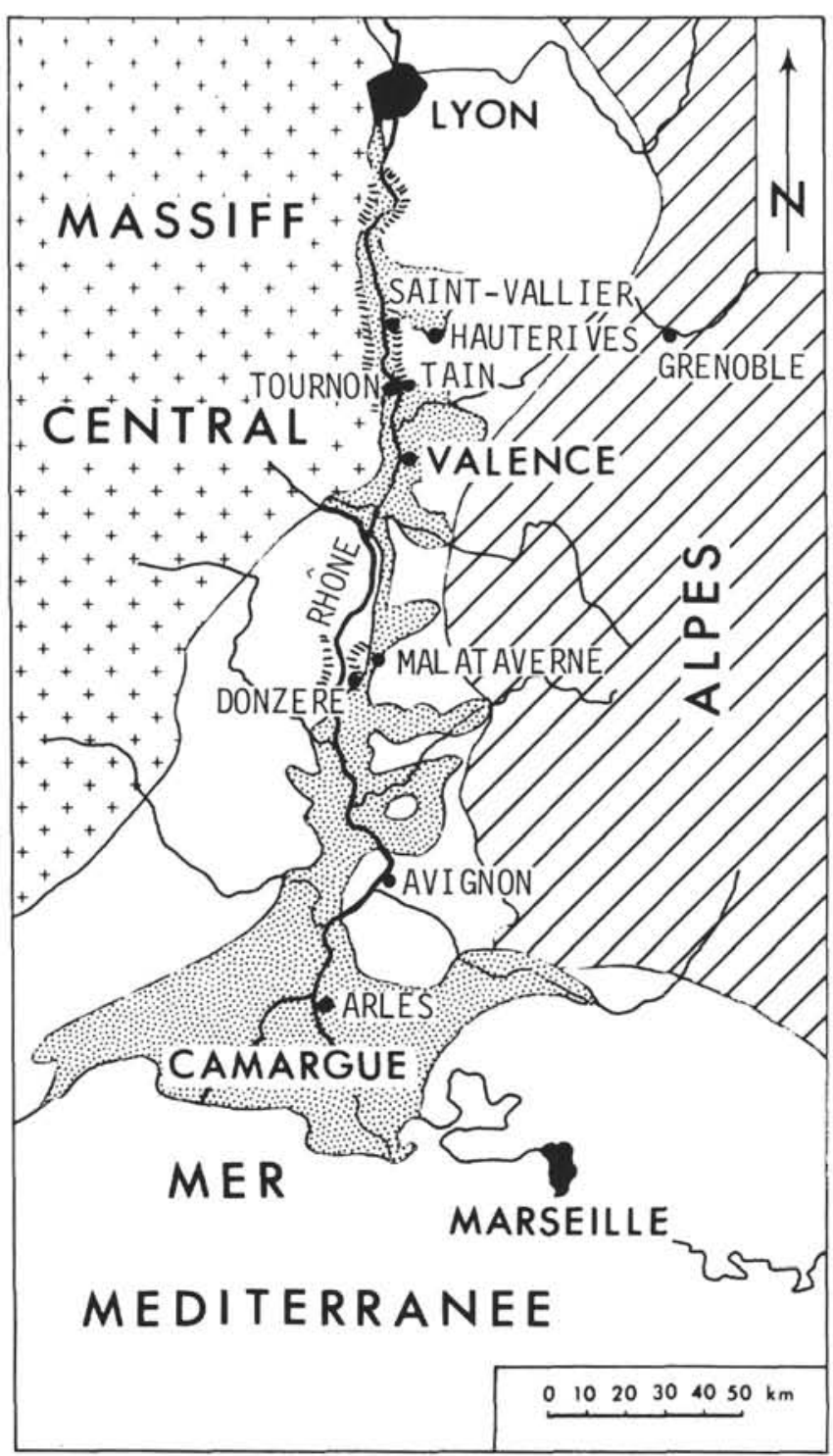

Figure 1. The present course of the Rhone River and the outline of the former "Piacenzian ria" (after R. Balésio, 1971).

This gorge, about $20 \mathrm{~km}$ long, is incised into homogeneous material of the Hercynian basement (granite and gneiss). From one end to the other, the deep wells have demonstrated that the present Rhône river lies some 200 meters above the pre-Pliocene thalweg. Since the area did not undergo differential tectonics either during or after Pliocene times, the morphologic surfaces created at the end of Miocene times have never been internally deformed. An intra-Pliocene subsidence can be excluded because it would have had to follow only the winding contours of the valley, a very unlikely possibility.

The Hercynian basement is levelled by an erosional surface. The post-Pliocene epeiorogenic uplift can be estimated at 200 to 300 meters since on both sides of the Rhône Valley this erosional surface lies some 350 meters above sea level. It represents a chronological datum and a paleogeographic indicator. From a chronological standpoint, it can be dated by means of the latest Tortonian layers which transgress over it. From a paleogeographical standpoint, it has been defined by Pelletier (1953) as a pediment dominated by an inselberg. At the time of such formation, this surface, now hanging, was sensibly at base level (i.e., at sea level). It represents for us the starting point for all the subsequent evolution.

When the Pliocene sea penetrated into the Rhône Valley, the sea level was near that of the present day. This is based on the conclusions of various authors that the Pliocene deposits were deposited under shallow water conditions. The difference of the Pliocene level with reference to the level of the sea in late Miocene times is at least 350 meters at a distance of some $200 \mathrm{~km}$ from the present-day shoreline. It results in a spectacular difference in the amount of erosion evidenced. Two hypotheses can be put forward in order to explain it. They are: either a general uplift related to the RhOdanian phase (see Fontannes, 1882, Faucher, 1927, Bourdier, 1962; Ballesio, 1971, Mandier, 1969) or a negative eustatic movement (see Depéret, 1865, Baulig, 1953). At this point we cannot make a choice between these two hypotheses; however, in the perspective of the Rhðdanian Phase, we remark bewilderment that such a vertical displacement would have been already achieved between this initial detection of the orogenesis (retreat of the sea, elaboration of the sediments on the slopes, etc.) and the commencement of actual channel cutting.

The formations representing the Pliocene infilling are marine near the base and brackish to fresh water in the upper part. What height did they reach? In the Rhône Valley at St. Desirat, marine clays referred to the Piacenzian are found at 220 meters above sea level (Mandier, 1969). It is an erosional limit in a gorge which has been deeply recut during Quaternary time. Outside the valley, Pliocene marine deposits are found up to 280 meters above sea level (Chateau de la Sizeranne); also, the lacustrine marls of Hauterives are as high as 300 meters. Near the end of the filling episode, the sea level was sensibly the same as in late Miocene times. In the meanwhile it should have dropped at least 350 meters.

According to the tectonic hypothesis, this implies a double movement of opposite trend, the result of which should be zero. These movements should have responded to strongly different rhythms: rapid uplift, followed by an extremely slow subsidence. We have to add to the preceding scheme a new Plio-Quaternary uplift on the order of 300 meters in order to account for the observed Quaternary cutting. In this perspective, from the end of the Miocene the area under discussion should have oscillated with movements of constant amplitude but of various rhythms. Since no precise argument has been proposed so far to justify these conditons, this hypothesis seems to us unrealistic.

On the other hand, the obstacles which led Denizot to limit the effects of the regression exclusively to the continental environment have been removed by the recent drillings in the area. So far, only the eustatic hypothesis can explain all the available data concerning the pre-Pliocene subaerial erosion. According to this model, we can more 
I, 1. TORTONIEN: phase of the peri-alpine sea

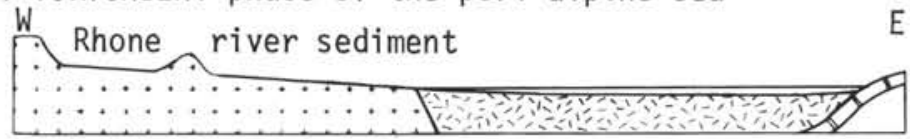

I,2. UPPER MIOCENE: lacustrine phase

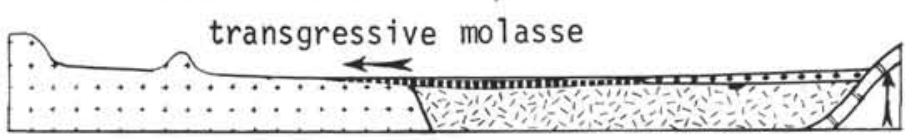

I,3. UPPER MIOCENE: Formation of a thin veneer of piedmont accumulations.
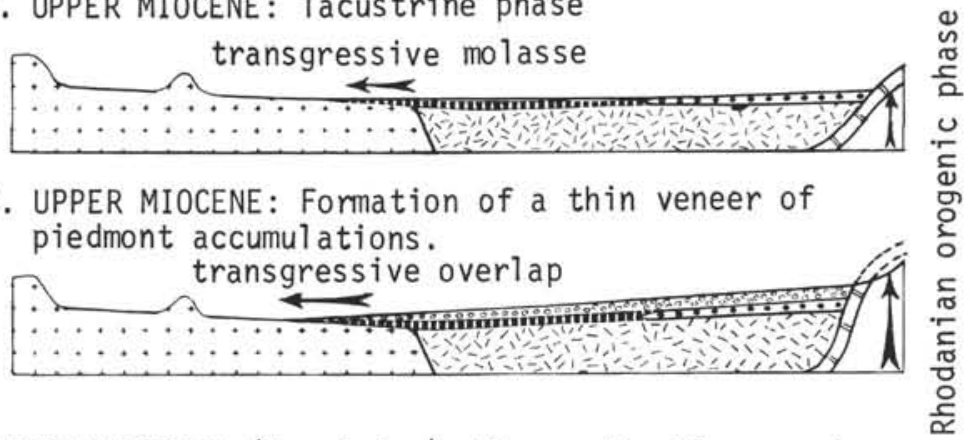

II. UPPER MIOCENE (Messinian): Phase of valley erosion,

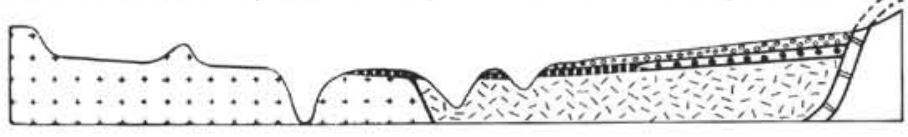

Messian eustatic movement

III,1. MIDDLE PLIOCENE (Plaisancian): Marine

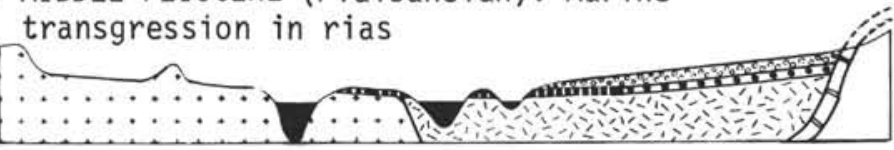

III,2. MIDDLE PLIOCENE (Hauterives Zone): lacustrine phase

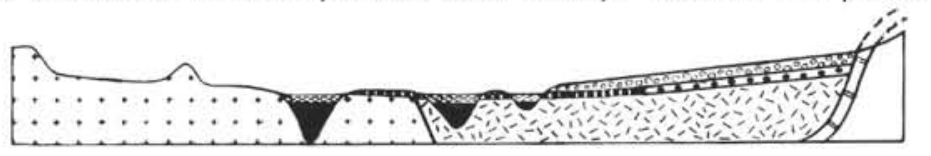

III,3. VILLAFRANCHIAN : formation of second piedmont

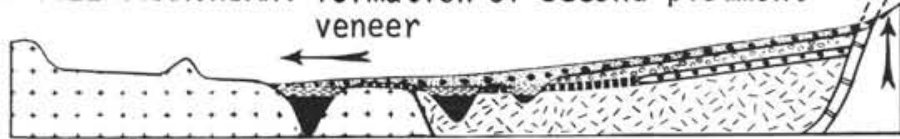

离

IV. QUATERNARY: phase of renewed valley erosion
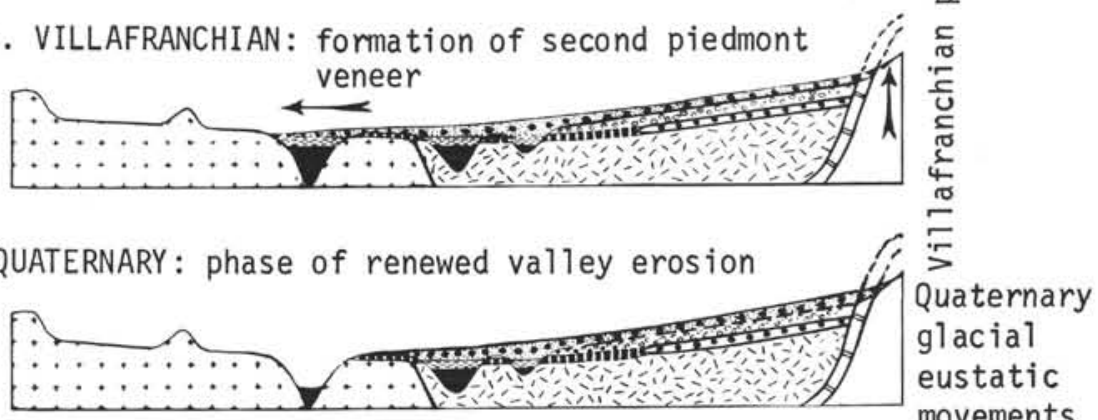

movements

Quaternary alluvium

Hauterives

.

Villafranchian conglomerates

\section{lacustrine marls}

Plaisancian blue marl

Upper Miocene conglomerates

[man Lacustrine and conglomerates of the same age

區楒罚 Vindobonian marine molasse

Mesozoic of the subalpine chains

$\because \ldots$ Hercynian basement

Figure 2. The evolution of the paleogeography of the central valley of the Rhone since the Miocene.

satisfactorily account for why the channel cutting always appears as a linear gorge and why it is deeper downstream than upstream. Taking into account the extended desicca- tion of the entire region we also better understand why the erosion took place only along the most important axis of the hydrographic network, without affecting the minor 
tributaries. The generalized desiccation accompanied by dryness is also documented by the data concerning the late Miocene floras (Grangeon, 1960; Ginsburg, 1968; MeonVilain, 1970) and faunas (Gaudry, 1873, Guerin and Mean, 1971) (landscape and population of steppe and/or savanna type) as well as by the data concerning the continental sedimentology (Chamley and Colomb, 1967) (rubefaction; predominance of montmorillonite).

Because of the local climatic conditions, only the rivers originating from the high drainage of the Alps would be expected to keep their connection with the very depressed erosional level.

Finally, the eustatic hypothesis alone can explain how the Pliocene transgression took place. Actually, in Camargue where the Pliocene succession is extremely thick, the transgression occurs in Tabianian times (clays with Sphaeroidinellopsis) while upstream, where the Pliocene filling is far less thick, the marine transgression occurred later in the Pliocene (blue marls referred to the Piacenzian).

Notwithstanding the impressive consequences of the Messinian drop in sea level, we cannot discount the Rhodanian orogenic phase. A chronologic displacement exists, indicating that the two phenomena are discrete. The regression comes after the orogenesis, being its consequence. This orogenesis in the sub-alpine domain (and at the epidermic level) has essentially a tangential component. In this respect, it differs from the following movementsPliocene and Pleistocene in age-which are of epeirogenetic type. This Rhodanian phase, associated with a world-wide eustatism (related to the orogenesis under discussion or to the beginning of the Antarctic glaciation?) indirectly caused the isolation of the Mediterranean basin. Under the influence of a dry climate, which was probably further deteriorated by the sinking of the water-table, this sea underwent a regression without precedent, during which the evaporites discovered in the abyssal plains were deposited.

\section{ACKNOWLEDGMENTS}

This paper was invited for inclusion into this chapter by M. B. Cita, following discussions at the Congress on the Mediterranean Neogene Stratigraphy at Lyon, in September 1971. She has kindly provided for translation of the original French text into English.

\section{REFERENCES}

Ballesio, R., 1971. Le Pliocène rhodanien. Docum. Lab. Géol. Univ. Lyon, H.S. 201.

Ballesio, R. and Truc, G., 1967. Contribution à l'étude du Néogène de la moyenne vallée du Rhône. Le Miocène supérieur et le Pliocène du Haut-Comtat Venaissin. Trav. Lab. Geol. Fac. Sci. Lyon. No. 14, 79.

Baulig, H., 1928. Le Plateau Central de la France et sa bordure méditerranéenne, A. Colin (éd.), 590 p. 1953. Les hauts niveaux de base du Pliocène. Rev. Geogr. Lyon. 28 (3), 205.

Beaufort, L., Bruneau, J., Crepin, A. and Jullian, Y., 1954. Ampleur de 1 l'érosion pontienne et du comblement pliocène en Camargue. Bull. Soc. géol. Fr. (Paris). sér. 4. 13,175 .

Bonnet, A. and Duboul-Razavet, C., 1952. Contribution à la connaissance du Bas-Rhône. Bull. Soc. géol. Fr. (Paris). ser. 6. 2, 123.
Bonnet, A., 1962. Liaison des tectoniques profondes et superficielles en Camargue. Bull Serv. Carte géol. France (Paris). 59 (269), 251.

Bourcart, J., 1962. La Méditerranée et la révolution du Pliocène. Livrë à la mémoire du prof. P. Fallot. Mém. $h$. sér. Soc. géol. Fr. 1, 103.

Bourdier, F., 1962. Le Bassin du Rhône au Quaternaire. Géologie et Préhistoire. Paris, éd. du C.N.R.S. 2, 364 p.

Carbonnel, G., 1969. Les ostracodes du Miocène rhodanien (Thèse) Docum. Lab. Géol. Fac. Sci. Lyon. 32 (fasc. 1-2), $469 \mathrm{p}$.

Chamley, H. and Colomb, E., 1967. Premières données sur la sédimentation argileuse du Miocène supérieur dans le bassin de Cucuron (Vaucluse). Présence de niveaux lacustres à attapulgite. C. R. Somm. Soc. géol. Fr. 230.

Combaluzier, C., 1932. Le Miocène de la Basse-Provence. Bull. Serv. Carte géol. France. 35 (182), 183 p.

Cornet, C., 1965. Evolution tectonique et morphologique de la Provence depuis l'Oligocène. Mém. Soc. géol. Fr. No. $103,1$.

Demarcq, G., 1961. Distinction entre les nappes miocène et pliocène de conglomérats à galets calcaires impressionnés dans la vallée du Rhône. Bull. Serv. Carte géol. France. (Paris) 58 (264), 179.

1964, Les faciès du Miocéne supérieur et du Pliocène inférieur et la limite Miocène-Pliocène dans la vallée du Rhône. C. R. $2^{\grave{e}}$ Colloque du Néogène méditerranéen. (Sabadell-Madrid) (fasc. 9), 77.

1970. Etudé stratigraphique du Miocène rhodanien. Mém. B.R.G.M. (Paris) No. 61, 257 p.

1971. Base de nos connaissances sur le Miocène de la valleé du Rhône. Docum. Lab. Géol. Univ. Lyon, H.S. 3 .

Denizot, G., 1939. Etude géologique de la Crau, la Camargue et l'étang de Berre. Trav. Lab. Géol. Univ. Marseille. 2, 4 .

1952. Le Pliocène dans la vallée du Rhône. Rev. Géogr. Lyon. XXVII (4), 327, fig. 9, pl. 1.

Deperet, C., 1895. Apercu sur la structure générale et l'histoire de la formation de la vallée du Rhône. Ann. Géogr. (Paris) 432.

Duboul-Razavet, C., 1956. Contribution à l'étude géologique et sédimentologique du delta du Rhône. Mem. Soc. géol. Fr. No. 76, 1.

Faucher, D., 1927. Plaines et Bassins du Rhône Moyen. Thèse Lettres Grenoble. Imprimerie Charpin et Veyne, Valence.

Fontannes, F., 1882. Note sur l'extension de la faune de la mer pliocène dans le S. E. de la France. Bull. Soc. géol. France (parris) sér. 3. 2, 103.

Gaudry, A., 1873. Animaux fossiles du Mont Léberon (Vaucluse). Etude sur les vertébrés. F. Savy (Ed.), Paris, $112 \mathrm{p}$.

Ginsburg, L., 1968. L'évolution du climat au cours du Miocène en France. Bull. Ass. Nat. Orléan., (Orléans, H.S.), XLI, 11 p.

Glangeaud, L., 1967. Epirogenèses ponto-plio-quaternaires de la marge continentale franco-italienne du Rhône à Genes. Bull. Soc. géol. de France. IX (7), 426.

Grangeon, P., 1960. Contribution à l'étude des terrains tertiaires, de la tectonique et du volcanisme du Massif du Coiron Trav. Lab. Geol. Fac. Sci. Grenoble. 36, 143.

Guerin, C. and Mein, P., 1971. Les principaux gisements de mammifères miocènes et pliocènes du domaine rhodanien. Docum. Lab. Géol. Univ. Lyon, H. S. 131.

Latreille, G., 1969. La sédimentation détritique au Tertiaire dans le Bas-Dauphiné et les régions limitrophes. Docum. 


\section{G. CLAUSON}

Mandier, P., 1969. La vallée épigénique du Rhône d'Andance à Tournon. Rev. Géogr. Lyon. XLIV (2), 117.

Mein, P. and Truc, G., 1966. Faciès et association faunique dans le Miocène supérieur continental du Haut-Comtat Venaissin. Trav. Lab. Géol. Fac. Sci. Lyon, H. S. No. 13, 273.
Meon-Vilain, H., 1970. Palynologie des formations miocènes supérieures et pliocènes du Bassin du Rhône. Doc. Lab. Geol. Fac. Sci. Lyon. No. 38, 167 p.

Pelletier, J., 1953. La bordure orientale du Massif Central de Vienne à Tournon. Rev. Géogr. Lyon. XXVIII (4), 357. 